\title{
THREE-DIMENSIONAL ANALYSIS OF FLEXIBLE PAVEMENTS SUBJECTED TO TRAFFIC LOADS USING FINITE ELEMENT TECHNIQUE
}

\author{
Abd Alla E. M. \\ Civil Engineering Department, Faculty of Engineering, Assiut University, \\ Assiut, Egypt.
}

(Received February 13, 2006 Accepted March 30, 2006)

\begin{abstract}
To predict pavement responses and performance due to external working loads, it is necessary to estimate stresses and deformations through pavement. When the induced strains are relatively small, they are usually evaluated using the theory of elasticity. Boussinesq's theory is used for this estimation through homogeneous soil. These responses in case of layered pavement system are less than those obtained for the ideal homogeneous case depending upon the stiffness of the layers. Semianalytical solutions are available to analyze the behaviour of elastic layered soil deposits subjected to surface loads. For more complex cases of soil deposits or loading conditions, it is necessary to perform numerical analysis using finite element technique. In addition, most of pavement materials do not linearly perform under the action of traffic loading. In this paper, the ANSYS version-8 program is used to analyze in three dimensions the behaviour of a layered pavement system under static loads indicating load transmission issues for a wide variety of materials stiffness, tire pressures and axle loads with dual wheels. Also linear and non linear analyses were preformed for different previously mentioned items. In this research, the pavement is modeled as a multilayered elastic system composed of a subgrade assumed to be an infinite medium upon which layers of finite thickness infinitely extended horizontally are laid. Furthermore, it is assumed that vertical loading, such as dual wheel loads are simultaneously applied to obtain stresses and deflections through the road pavement. On the basis of this research, remarkable conclusions are drawn out.
\end{abstract}

\section{INTRODUCTION}

Flexible pavements are classified by a pavement structure having an asphalt wearing surface on the top of layers of granular base and subbase being used to protect the subgrade from being over-stressed. Pavement responses are affected by both load and tire pressure. But, the load has a greater effect than tire pressure. The effect of increased tire pressure is significant in the asphalt surface layer in terms of vertical compressive stresses, and the magnitude of the maximum tensile strain at the bottom of asphalt base layer increases with the increased tire pressures. Further more, tire type, 
axle load, and axle configuration have significant effects on those responses. When the induced strains due to external loads are relatively small, stresses and deformations are usually estimated using the theory of elasticity. Semi-analytical and analytical solutions are available to analyze the behaviour of elastic layered pavement subjected to surface loads. In solutions concerning the analysis of layered pavement systems under traffic load, the pavement layers are considered as homogeneous, linear elastic, isotropic and the loading is considered as static. These methods work reasonably well if the pavement system behaves as a linear elastic system. In the real situation, heterogeneous pavement layers behave far from such ideal conditions. Pavement materials are not behaving in a linear elastic manner and the materials behave in a nonlinear manner. For design of relatively thick asphalt construction, linear elastic theory for a wheel load may be valid, where for thin asphalt construction the non-linear characteristics of the granular layers and soil dominate the response to wheel load, nonlinear analysis is required. In addition, the soil should operate at stress levels within the elastic range. For pavement analysis, while considering the heterogeneity and nonlinearity condition of the pavement structure, it is necessary to perform numerical analysis using finite element technique. The finite elements programs can easily handle complex geometry, boundary conditions and materials [1-13].

In this paper, the ANSYS program version-8 [14] is used to model the flexible pavement as a finite element model, with defined boundary conditions and to investigate the effect of loading when combined with linear and non-linear characteristics of pavement materials of the layers. Also, the effect of different cases of traffic loading on the stresses and deformations through the layers is investigated.

\section{BACKGROUND}

The flexible pavement responses can be derived from either the results of road trials and experiments and from observations and measurements made on roads carrying normal traffics or analytical and finite element solutions, requiring some of the mechanical properties of pavement materials with elastic linear behaviour, summarized as follows [15]:

One-layer Elastic System: This approach has been developed by Boussinesq, who assumed that the soil is weightless and unstressed before the application of the load and the change in its volume is neglected; the subgrade, subbase, base and surfacing layers form one semi-infinite linearly elastic, isotropic solid; and stress and deformation distributions are symmetrical with respect to the vertical axis of acting load [1]. Furthermore, the maximum vertical stress $\left(\sigma_{z}\right)$ at any depth $(z)$ below the surface due to a uniformly distributed circular load $\left(p_{o}\right)$ at the surface is as follows:

$$
\sigma_{z}=p_{o}\left[1-\frac{1}{\left(1+(a / z)^{2}\right)^{1.5}}\right]
$$

where: $a=$ radius of circular load pressure

Also, he suggested the following equation for determining deflection under the center of the loaded area assuming a value of one-half for Poisson's ratio: 


$$
\Delta=\frac{p_{o} \cdot a}{\mathrm{E}} F
$$

where: $\Delta=$ vertical displacement; $\mathrm{p}=$ pressure intensity; $\mathrm{a}=$ radius of loaded area,

$\mathrm{E}=$ modulus of deformation (or modulus of elasticity);

$F=$ deflection factor depends on the depth radii ratios and;

$$
F=1.5\left\{1 /\left[1+(\mathrm{a} / \mathrm{z})^{2}\right]\right\}^{0.5}
$$

$z=$ depth blew loaded area of compressible layer.

When the soil mass consists of layered strata of finer and coarser materials or nonisotropic soils, the Boussinesq equations may not provide reliable solution.

Two layers System: In the solution, certain essential assumptions are adopted such as the materials in the layers are homogeneous, isotropic, and elastic; the surface layer is infinitely long in the lateral direction but of finite depth, whereas the underlying layer is infinite in both horizontal and vertical directions; the layers are in continuous contact and the surface layer is free of shearing and normal stresses outside the loaded area [1]. The total surface deflection $\Delta_{\mathrm{t}}$ for two layer system can be obtained by the following equation:

$$
\Delta_{t}=1.5 \frac{p_{o} \cdot a}{\mathrm{E}_{s}} F_{1}
$$

where $\mathrm{E}_{\mathrm{s}}=$ modulus of elasticity of lower layer,

$F_{l}=$ dimensionless factor depending on the ratio of moduli of elasticity of the subgrade $\left(\mathrm{E}_{\mathrm{s}}\right)$ and pavement $\left(\mathrm{E}_{\mathrm{p}}\right)$ as well as the depth to radius ratio,

$p_{o}, a=$ have the same previous significance.

Huang [1] has developed interface factor charts for determining interface deflection $\Delta_{\mathrm{s}}$ from an extension of Burmister's two layer theory as follows:

$$
\Delta_{\mathrm{s}}=F\left(p_{o} \cdot a / E_{s}\right)
$$

where $F$ is a deflection factor depending on $E_{p /} E_{s}$ and $z / a$ ratios.

Multi-layers Elastic System: A pavement structure is considered as a layered elastic solid with the lowest layer semi-infinite in extent. Burmister provided analytical expressions for stresses in three layer elastic systems, which had been expanded by Jones and Peattie, where vertical stress at the interfaces of layers due to the applied stress $\left(p_{o}\right)$ on the plate at the surface, has been obtained in graphical representations as a stress factor value $\left(\mathrm{ZZ}_{1}\right.$ and $\left.\mathrm{ZZ}_{2}\right)$ given as [1]:

$$
\begin{aligned}
& \sigma_{\mathrm{z} 1}=\mathrm{p}_{\mathrm{o}}\left(Z_{1}\right) \\
& \sigma_{\mathrm{z} 2}=\mathrm{p}_{\mathrm{o}}\left(Z_{2}\right)
\end{aligned}
$$

Conversion of the Layers of Pavement Section: In this approach, it is assumed that the pavement layers are acting as a single homogeneous incompressible layer considering stiffness factor of layers. The total stress and deflection in the subgrade consists of two components, the first results from the applied wheel load and the 
second from the overlaying materials. The vertical stress in subgrade $\left(\sigma_{z}\right)$ can be obtained by using modified form of Boussinesq's equations considering equivalent height of pavement layers as follows [16]:

$$
\sigma_{z}=p_{o}\left[1-\frac{\left(h \sqrt[3]{E_{1} / E_{s}}+k h \sqrt[3]{E_{2} / E_{s}}\right)^{3}}{\left\{r^{2}+\left(h \sqrt[3]{E_{1} / E_{s}}+k h \sqrt{E_{1} / E}\right)^{2}\right\}^{3 / 2}}\right]+\left(\gamma_{1} h+k h \gamma_{2}\right)
$$

where: $p_{o}=$ tire pressure

$r=$ radius of contact area,

$h_{1}$ and $h_{2}=$ thickness of base and subbase, respectively,

$E_{1}, E_{2}, E_{s}=$ modulus of elasticity of base, subbase, and subgrade, respectively,

$k=h_{2} / h_{1} ; h_{1}=h, \mathrm{~h}_{1}, \mathrm{~h}_{2}$, are thickness of base and subbase, respectively,

$\gamma_{1}, \gamma_{2}=$ unit weight of the base and subbase, respectively

For more complex cases of layered pavement or loading conditions, it is necessary to use means of numerical techniques such as the finite element method for structural analysis of flexible pavement system. In recent years, some software programs permit the calculation of stress and deformations at any point in a particular layer for one or more loads for multilayer system.

Two-Dimensional Finite Element Analysis of Multi-layered Pavement Systems: In these methods each layer of the multi-layer linear elastic pavement structure is characterized by its Young's Modulus and its Poisson's ratio. The stresses, strains and deflections at specified distances from the load are then theoretically calculated, assuming a semi-infinite subgrade and infinite lateral boundaries. Layers thicknesses and material properties are adjusted until the computed responses are lower than elastic criterion. For multi-layered flexible pavement, two relations were developed using 2-D finite element analysis [12, 17]. The derivative relationship between the total equivalent height of pavement $\left(\mathrm{H}_{\mathrm{e}}\right)_{\mathrm{t}}$ and the relative stress at subgrade with respect to applied one at pavement surface is plotted as shown in Fig. 1. Also, the relationship between the deflection factor, $\mathrm{F}$ and $\left(\mathrm{H}_{\mathrm{e}}\right)_{\mathrm{t}}$ is plotted as shown in Fig. 2. In these relations; the pavement layers thickness $\left(\mathrm{h}_{\mathrm{p}}\right)$ is replaced by equivalent subgrade material $\left(h_{\mathrm{e}}\right)$. Pavement surface deflection beneath the center line of applied load $(\Delta)$ may be expressed as follows:

$$
\Delta=\left(2 \mathrm{p}_{\mathrm{o}} * \mathrm{a}\right)\left(1-\mathrm{v}_{\mathrm{s}}^{2}\right) * \mathrm{~F} / \mathrm{E}_{\mathrm{s}}
$$

where $\mathrm{p}_{\mathrm{o}}=$ applied contact pressure, $\mathrm{a}=$ radius of applied contact pressure, $\mathrm{F}=$ deflection factor, $\mathrm{E}_{\mathrm{s}}$ and $\mathrm{v}_{\mathrm{s}}=$ modulus of elasticity and Poisson's ratio of subgrade, respectively.

\section{THREE-DIMENSION FINITE ELEMENT ANALYSIS OF MULTI-LAYERED FLEXIBLE PAVEMENT}

For 3-dimensional analysis of pavement structure of non homogeneous materials, it can be efficiently used for the analysis, is ANSYS Program Version-8 [14]. This software is used in this research study for elastic linear and non-linear behaviour of pavement materials under various loading conditions as follow: 


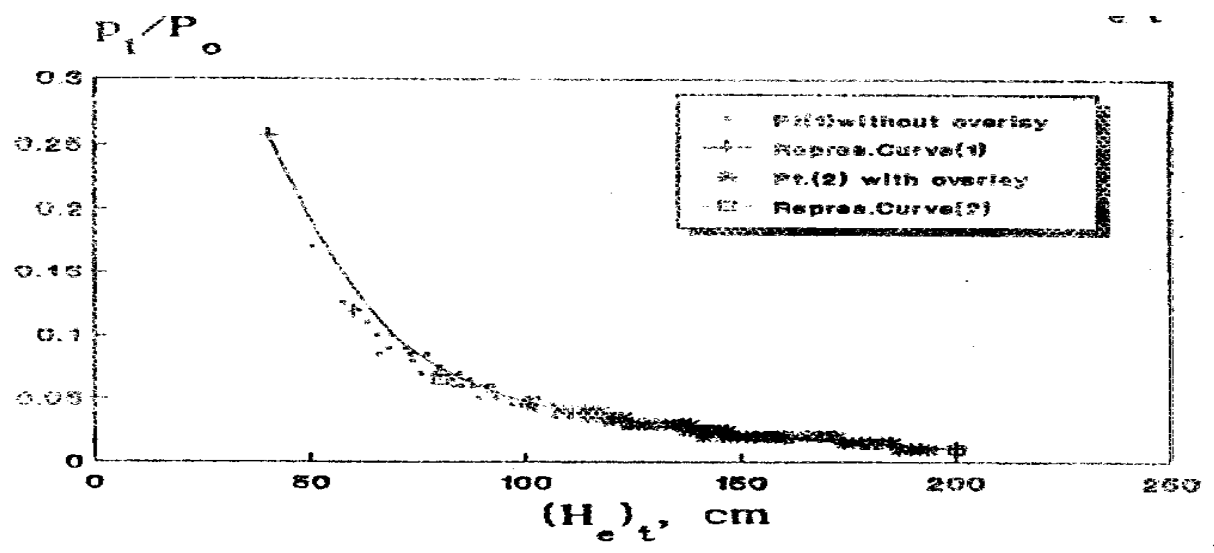

Fig. 1: Relationship between the relative stress at subgrade / applied one $\left(p_{1} / p_{o}\right)$ and equivalent pavement height $\left(H_{e}\right) t$.

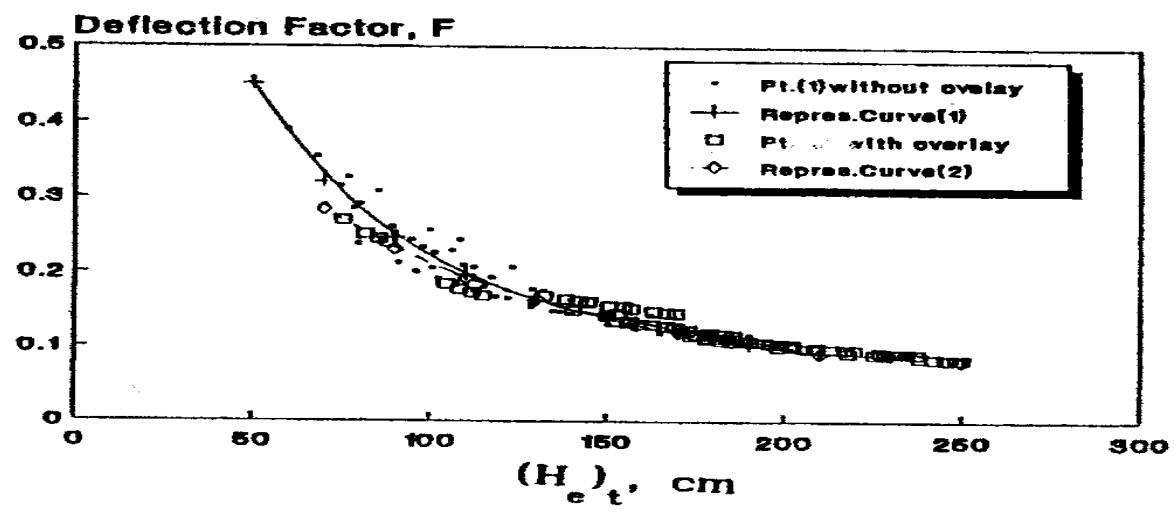

Fig. 2: Relationship between the deflection factor, F, and equivalent pavement height $\left(\mathrm{H}_{\mathrm{e}}\right)_{\mathrm{t}}$.

\subsection{Case of Elastic-linear Characteristics of Pavement Materials}

For analysis of pavement structure, the layers thicknesses in the pavement model have been chosen such that they are close to those of the existing pavement. The pavement structure selected for this study consists of $50 \mathrm{~mm}$ of dense graded asphalt concrete surface course and $50 \mathrm{~mm}$ thick binder course, a $150 \mathrm{~mm}$ thick granular crushed limestone layer as the base course, a $250 \mathrm{~mm}$ thick of gravel-sand soil as the subbase course and a subgrade (silty soil) at the bottom. The configuration for the structure used in the analysis is illustrated in Fig. 3. The material characteristics used in the analyses, considered to be representative of the various layers in the selected pavement structures, are summarized in Table 1.

To analyze the pavement system shown in Fig. 3, the pavement is modeled as a finite element model, using ANSYS Program Version-8. The pavement configuration 
selected for calculation is shown in Fig. 4. The pavement block is modeled with SOLID45 brick elements quadratic with 8-node. The element has three degrees of freedom at each node: translations in the nodal $\mathrm{x}, \mathrm{y}$, and $\mathrm{z}$ directions and rotation are not allowed for all nodes [14]. The finite element model representing the pavement considered in this analysis, and mesh generation are shown in Fig. 5.

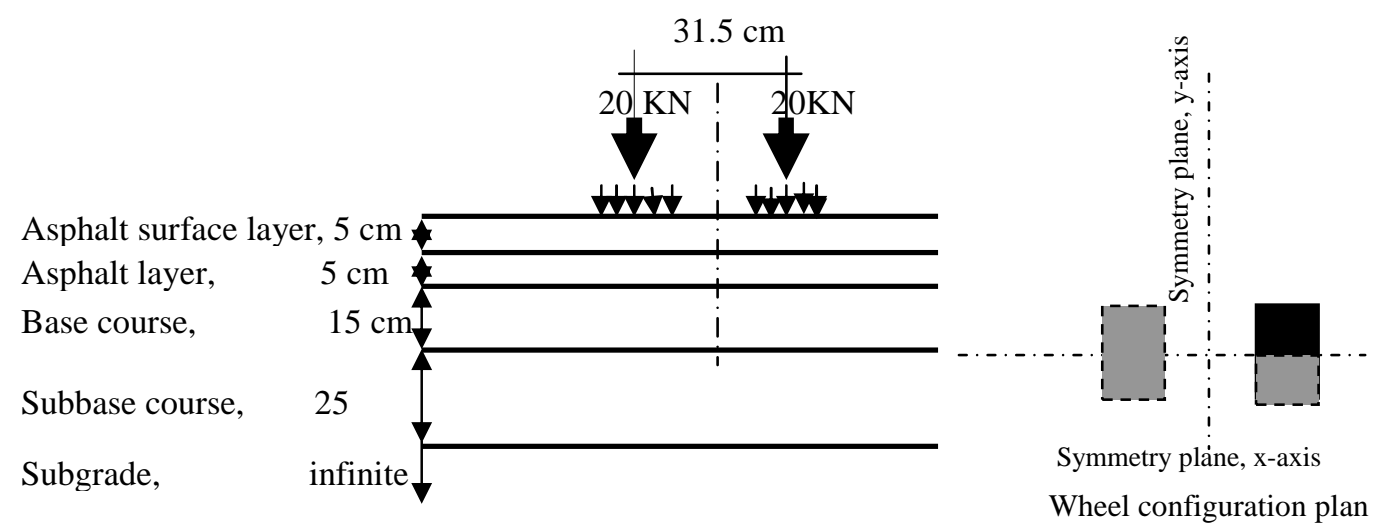

Figure 3: Pavement configuration.

Table 1: layer thickness and elastic material properties used for analysis.

\begin{tabular}{|l|l|c|c|c|c|}
\hline Layer & Material & $\begin{array}{c}\text { Thickness, } \\
\mathrm{cm}\end{array}$ & $\begin{array}{c}\text { Unit Weight, } \\
\mathrm{kg} / \mathrm{m}^{3}\end{array}$ & $\begin{array}{c}\text { Young's Modulus, } \\
\mathrm{kg} / \mathrm{cm}^{2}\end{array}$ & $\begin{array}{c}\text { Poisson's } \\
\text { Ratio }\end{array}$ \\
\hline 1 & Surface layer & 5 & 2400 & $10000-30000$ & 0.4 \\
\hline 2 & Binder course & 6 & 2350 & $5000-15000$ & 0.4 \\
\hline 3 & Base & 15 & 2200 & 1500 & 0.3 \\
\hline 4 & Sub-base & 25 & 2000 & 1000 & 0.3 \\
\hline 5 & Subgrade & infinite & 1500 & 200 & 0.45 \\
\hline
\end{tabular}

The boundary conditions are defined at the nodes where the displacements in horizontal and vertical directions can be restrained. The following conditions are applied with reference to Fig. 4, when defining the boundary conditions.

- The vertical displacements of the nodes on the bottom plane (plane ABCD) of the model are fixed.

- The plane ADGF is considered as plane of symmetry between the two wheels, thus the orthogonal displacements to the plane are prevented.

- The plane ABEF is considered as vertical plane passing through midway of one wheel, thus the orthogonal displacements to the plane are prevented .

This configuration gives more realistic representation of the pavement, and the load is also repeated on either side of the symmetry boundary. The analysis is run in a plane strain configuration. In this type of analysis, the loading is applied as traffic static loading of axle equal to $80 \mathrm{kN}$ applied through a dual wheel assembly spaced by $31.5 \mathrm{~cm}$. The $20 \mathrm{kN}$ wheel load is assumed to be uniformly distributed over the contact 
area between tire and pavement. A contact pressure equals to $570 \mathrm{KN} / \mathrm{m}^{2}$ (tire pressure of commercial vehicle) is assumed, i.e. $5.77 \mathrm{~kg} / \mathrm{cm}^{2}$. The contact area can be represented by two semicircles and rectangle as shown in Fig. 6. This previous shape is converted to a rectangle as suggested by Ref. [9], having an area of $0.5228 \mathrm{~L}^{2}$, the same contact area of each wheel. Since, $\mathrm{L}=\sqrt{\mathrm{W}} /(570 \times 0.5228)=26 \mathrm{~cm}$, then the contact area has the dimensions of 22.6 x $15.6 \mathrm{~cm}$ as shown in Fig 6 .

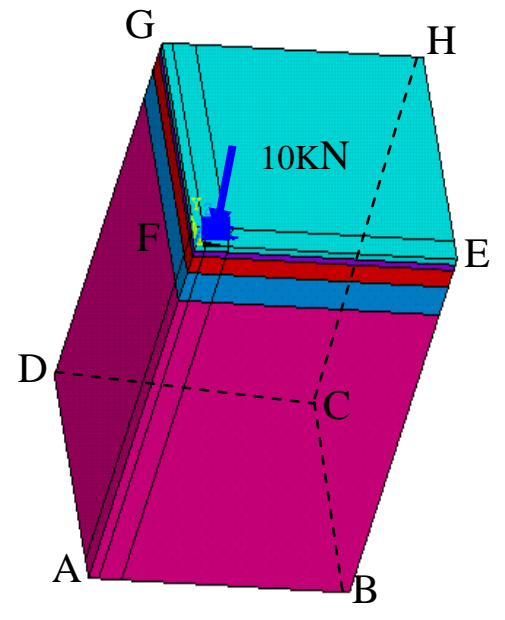

Fig. 4: Pavement configuration used in the analysis.

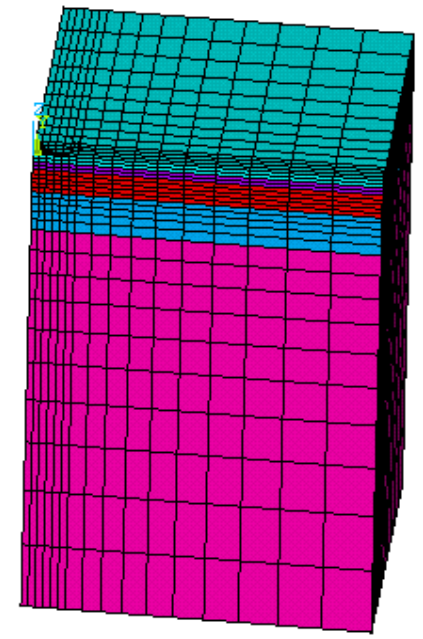

Fig. 5: Three-dimensional view of the finite element model.

Due to symmetry, the pavement under a half wheel load is considered in the analysis. A pavement block under half wheel load, having a length of $183.6 \mathrm{~cm}$, width of $131.35 \mathrm{~cm}$, and a depth of $300 \mathrm{~cm}$, is considered for the analysis as shown in Fig. 4. The effect of increasing contact pressure is conducted. Therefore, another contact pressure of $8.44 \mathrm{~kg} / \mathrm{cm}^{2}$ on the same selected contact area is used for analysis. Furthermore, the effect of increasing axle load was studied. Thus other runs were performed for a model representing the pavement under the effect of an axle loads of 9.3t $13.6 \mathrm{t}$ for contact pressure of both 5.77 and $8.44 \mathrm{~kg} / \mathrm{cm}^{2}$ and pavement block under half wheel load, having a length of $191.1 \mathrm{~cm}$ and width of $152.9 \mathrm{~cm}$, and a depth of $300 \mathrm{~cm}$, are considered.

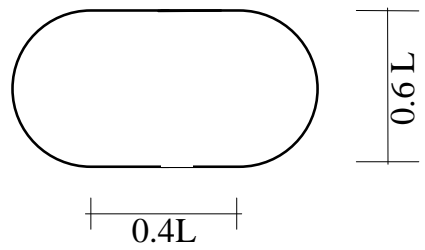

Fig. 6-a: contact area between tire and pavement surface.

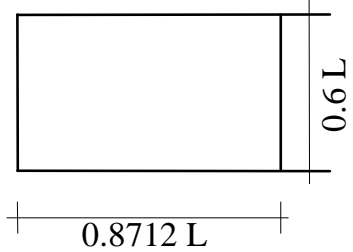

Fig. 6-b: Equivalent contact area. 


\section{2 Case of Elastic-non linear Characteristics of Pavement Materials}

The behavior of unbound pavement materials with thin asphalt layer is certainly nonlinear and stress dependent, even at low traffic stresses. For pavement analysis, a nonlinear finite-element model with stress dependency is suitable for calculating a reduced horizontal tension in the bottom half of unbound aggregate base layers. It is also noted that the effects of nonlinearity and the varying stress-dependent modulus and Poisson's ratio, especially in the base layers, could be substantial, and the proper selection of material properties is very important to improve the prediction of those behaviors [11].

Therefore, the finite element computer program ANSYS Program Version-8 was used for pavement analysis considering the non linearity of the pavement materials. The Durcker-Brager yield criterion is used in this study as a simple pressure dependent failure criterion. It can be viewed as a smooth approximation to the Mohr- Coulomb criterion. Since the values of c (cohesion) and $\varphi$ are determined by using conventional triaxial compression tests, they are different from those determined under plane strain conditions. The value of Drucker Brager constant can be expressed as [18]:

$$
\tan \alpha=\frac{\tan \varphi}{\sqrt{\left(9+12 \tan ^{2} \varphi\right)}}
$$

where $\alpha=$ angle of flow (the inclination of yield surface),

$\varphi=$ angle of internal friction

The values of cohesion, angle of internal friction and angle of flow in addition to the initial values of Young's modulus and Poisson's ratios for different materials used in the analysis for non linear behavior of pavement layers are assumed and shown in Table 2 [9, 18 and 19]. The pavement structure, configuration and loading conditions selected for calculation; finite element mesh and the boundary conditions are similar as in the case of linear analysis (Figs. 3-5). The 3-dimensional analysis is run in a plane strain configuration. The pavement block is modeled with SOLID 45 brick elements.

Table 2: layer thickness and elastic material properties used for non linear analysis.

\begin{tabular}{|c|l|c|c|c|c|c|}
\hline Layer & Material & $\begin{array}{c}\text { Initial Young's } \\
\text { Modulus }\left(\mathrm{kg} / \mathrm{cm}^{2}\right)\end{array}$ & $\begin{array}{c}\text { Poisson's } \\
\text { Ratio }\end{array}$ & $\begin{array}{c}\mathrm{C}, \\
\mathrm{kg} / \mathrm{cm}^{2}\end{array}$ & $\begin{array}{c}\text { Friction } \\
\text { angle, } \varphi\end{array}$ & $\begin{array}{c}\text { Angle } \\
\text { of flow }\end{array}$ \\
\hline 1 & surface layer & $10000-30000$ & 0.4 & 2.5 & 35 & 10 \\
\hline 2 & Binder course & $5000-15000$ & 0.4 & 2 & 35 & 10 \\
\hline 3 & Base & 1500 & 0.3 & 0.01 & 55 & 14 \\
\hline 4 & Sub-base & 1000 & 0.3 & 0.03 & 45 & 12 \\
\hline 5 & Subgrade & 200 & 0.4 & 1.0 & 20 & 2 \\
\hline
\end{tabular}

\section{The vertical stress $\sigma_{z}$ load step increments curve}

To check the accuracy of the used program, Figure 7 shows the relationship between the stress $\sigma_{z}$ and the increments (load steps) of equivalent single wheel load at specified point (at surface) through the center line of dual wheel load assembly obtained from linear and nonlinear solutions using the ANSYS program. The nonlinearity solution performed using Drucker Brager criterion is compared by linear solution. The linear 
solution assumed that there is no yield surface and then the behavior of materials is always elastic. But in non linear solution, the yield surface is assumed as Drucker Brager criterion. Therefore, if the stress acting on the material is inside the yield surface, the partial solution is linear followed by nonlinear solution due to the hardening of material where the yield surface expanded isotropically until it fails.

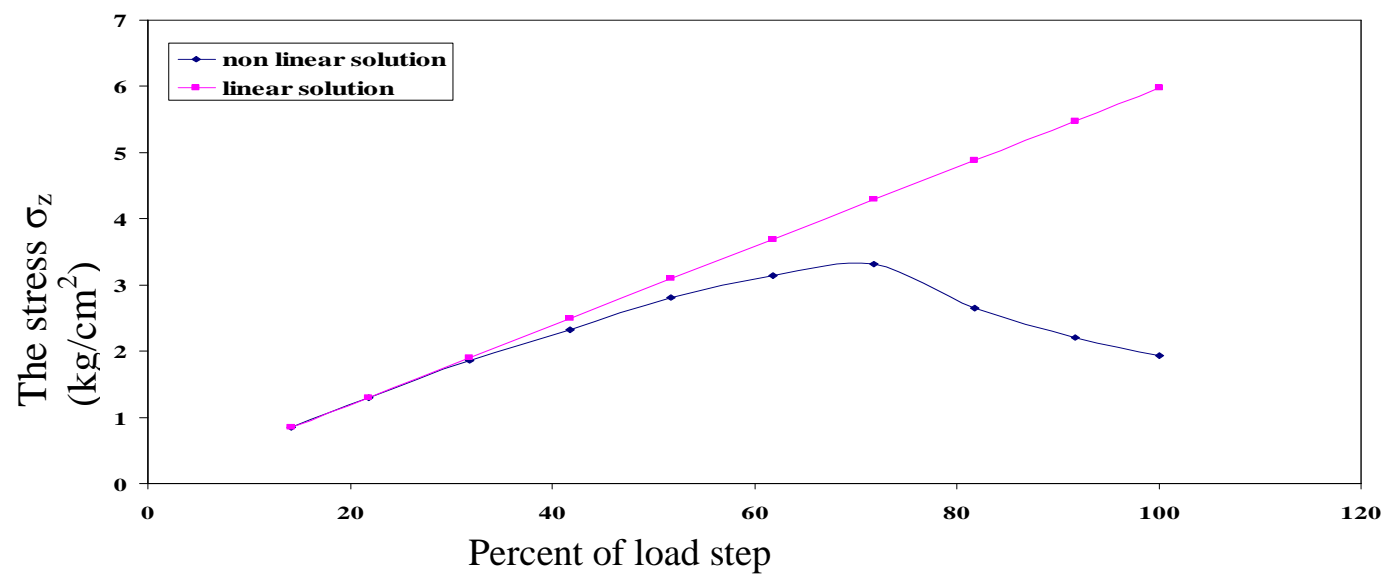

Fig. 7: The linear and non-linear solutions of selected flexible pavement.

\section{PAVEMENT ANALYSIS RESULTS AND DISCUSSION}

The results of all of the analyses obtained in the modeled pavement structures are presented. These results are given in the sequence in which they were accomplished to illustrate the process used to arrive at a proper knowledge of predicted performance of pavement structure.

The effect of pavement depth on deflection and stresses were determined. These responses were obtained at lines of symmetry (x-axis and y-axis) and through C.L. of wheel. Figure 8 shows the locations at which deflections and stresses were determined, analyzed and described in the following sections

\section{Locations}

On surface

On base surface

At subgrade

$\longrightarrow \frac{\text { Asphalt Concrete }}{\text { Base }}$

Figure 8: Pavement surface locations at which deflection and stress were determined.

\section{1 Case of Elastic-linear Characteristics of Pavement Materials}

The effect of pavement depth on deflections and stresses due to tire pressure $\left(8.44 \mathrm{~kg} / \mathrm{cm}^{2}\right)$ were presented in Figs. 9-10. From these figures, it is noticed that the deflection decreases as pavement depth increases. The deflection at line of symmetry 
(x-axis) and through C.L. of wheel decreases as the distance of line of symmetry increases depending on pavement depth and on wheel assembly configuration for shallow ones.

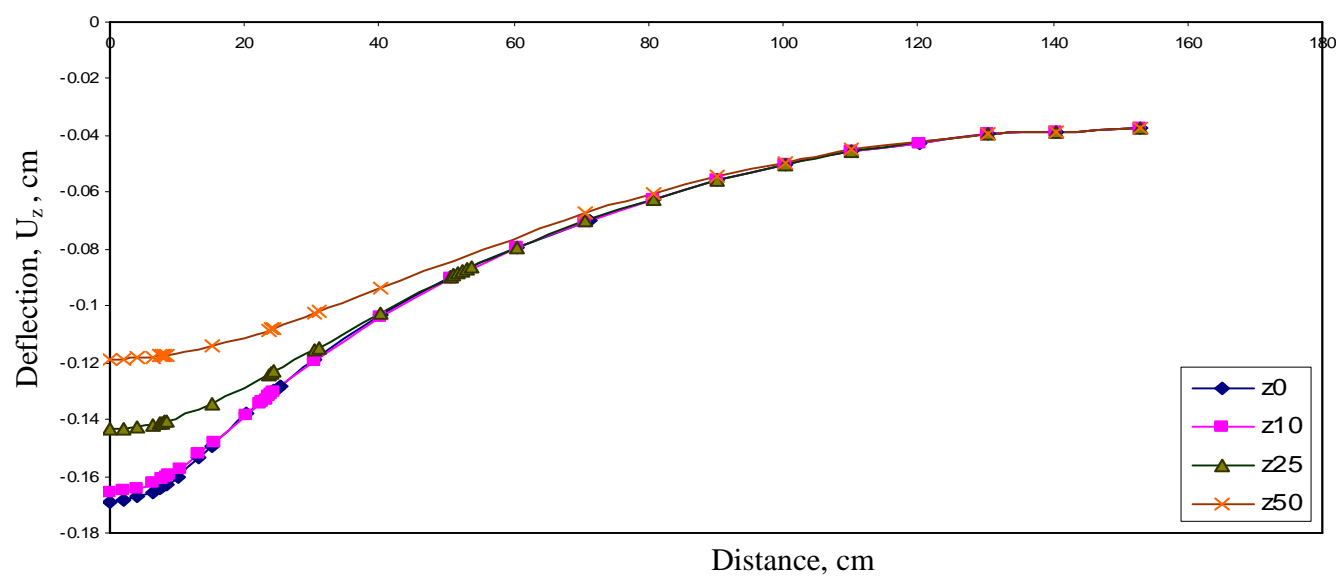

Figure 9: Deflection through wheel C.L. and different depths $(0,10,25,50 \mathrm{~cm})$.

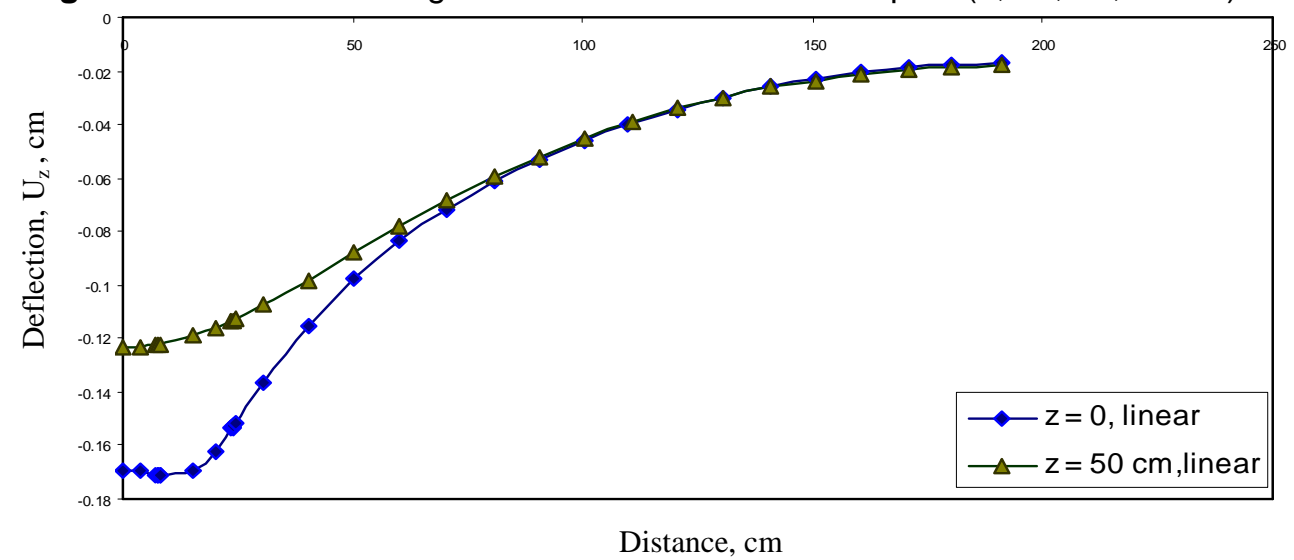

Figure 10: Deflection of pavement surface and at depth of $50 \mathrm{~cm}$ through $\mathrm{x}$-axis

The stress due to tire pressure decreases as pavement depth increases, and depends on wheel assembly configuration for shallow depths as shown in Figs. 11-12. The stress at shallow depths through C.L. of wheel is greater than that at y-axis line of symmetry (C.L. of wheel assembly configuration). The maximum vertical stress at depth $50 \mathrm{~cm}$ using firstly, Boussinesq's theory and modified equation (8), secondly 2-D analysis and Fig. 2, reached $-0.30 \mathrm{~kg} / \mathrm{cm}^{2}$, while it is equal to $-0.39 \mathrm{~kg} / \mathrm{cm}^{2}$ according to the present analysis, i.e. exceeds by $30 \%$ of that obtained according to comparison cases. Also, the maximum surface deflection obtained using 2-D analysis and derivative relation given in Fig. 2 equals $0.188 \mathrm{~cm}$, while it reached $0.17 \mathrm{~cm}$ according to the present analysis i.e. less by $10 \%$ of that according to the 2-D analysis. These deviations may be attributed to the assumed circular contact area and dimensional effects in previous works. 


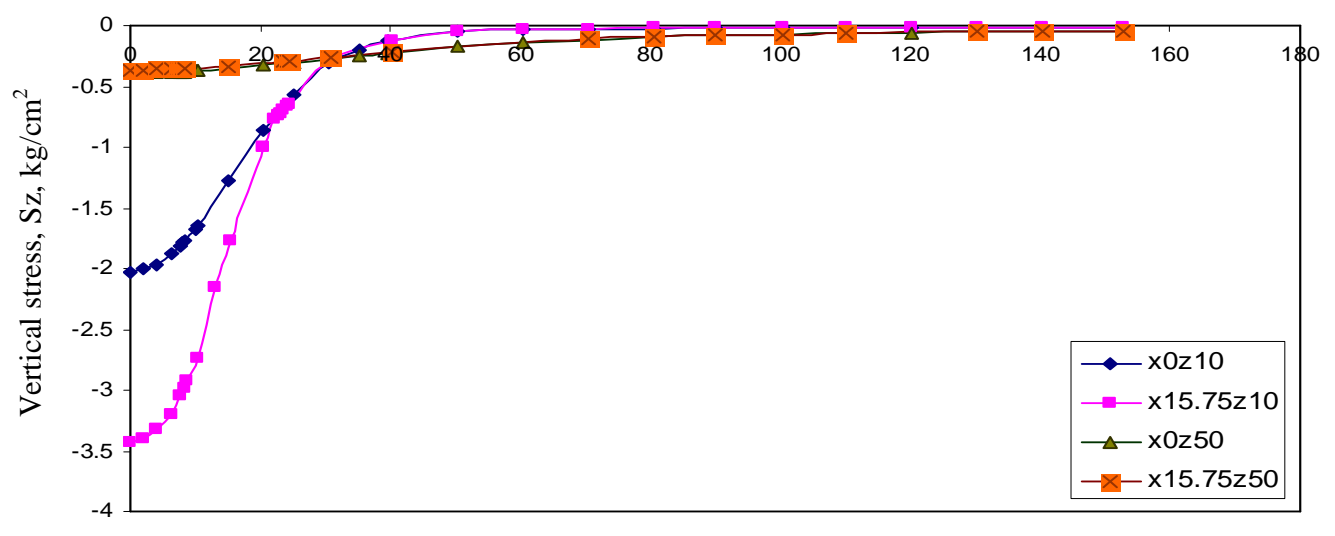

Distance, $\mathrm{cm}$

Figure 11: Vertical stresses at depths of 10 and $50 \mathrm{~cm}$ through $\mathrm{y}$-axis and C.L. of wheel.

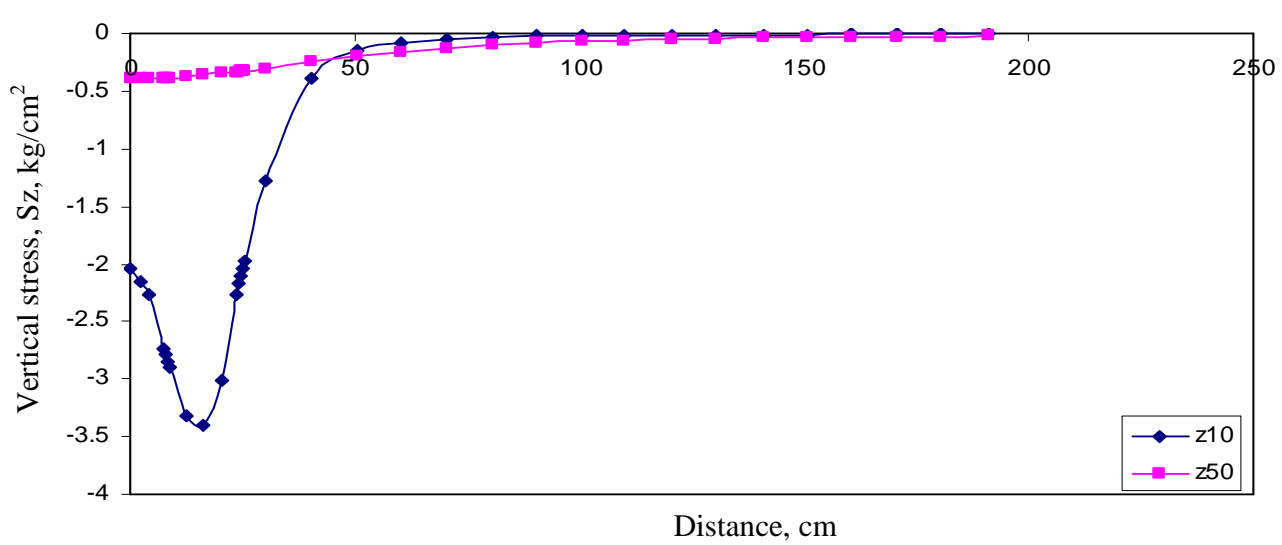

Figure 12: Vertical stresses at depths of 10 and $50 \mathrm{~cm}$ through $\mathrm{x}$-axis.

\subsection{Case of Elastic-non linear Characteristics of Pavement Materials}

The deflection due to tire pressure decreases as pavement depth increases for non linear performance of pavement materials as presented in Figs. 13-14. Also, these deflections under loading zone at shallow depths decrease depending on wheel assembly configuration. The value of deflection and stress considering non linearity are larger than those obtained from linear analysis as given in Figs. 13-15. Considering non linear analysis, vertical stresses through C.L. of wheel are larger than those through C.L. of dual wheel assembly at shallow pavement depths, but the differences are negligible at large depths, i.e., dual loads act as a unit load as shown in Fig. 16.

The different stresses $\left(S_{x}, S_{y}, S_{z}\right)$ at the bottom surface of lower surface layer are shown in photos given in Figs. 17a-17c. So, the maximum shear tensile stress reached $1.4-1.86 \mathrm{~kg} / \mathrm{cm}^{2}$, while the vertical compressive stress is equal to $2.99 \mathrm{~kg} / \mathrm{cm}^{2}$ but, vertical compressive stress reached $0.56 \mathrm{~kg} / \mathrm{cm}^{2}$ at subgrade surface, Fig. 17d. Figure 17e illustrates that the pavement responses almost happen within semi-conical zone and sharply decreased beneath surface layer and extends to 2-3 times of wheel breadth roundly. 


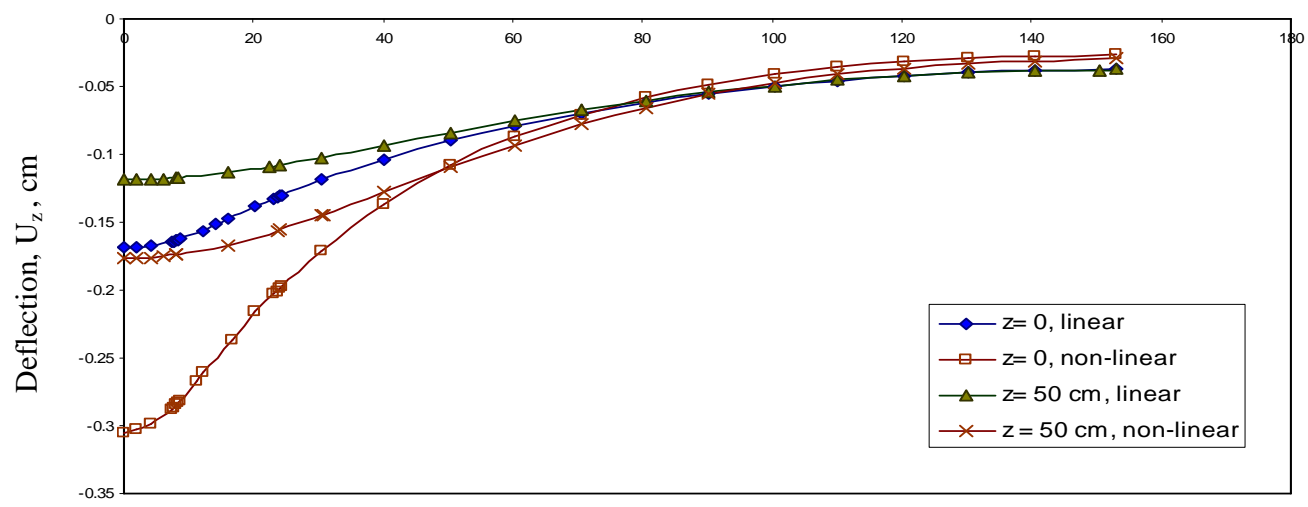

Distance, $\mathrm{cm}$

Figure 13: Comparison of linear and non linear deflections of pavement surface and at depth of $50 \mathrm{~cm}$ through C.L. of wheel.

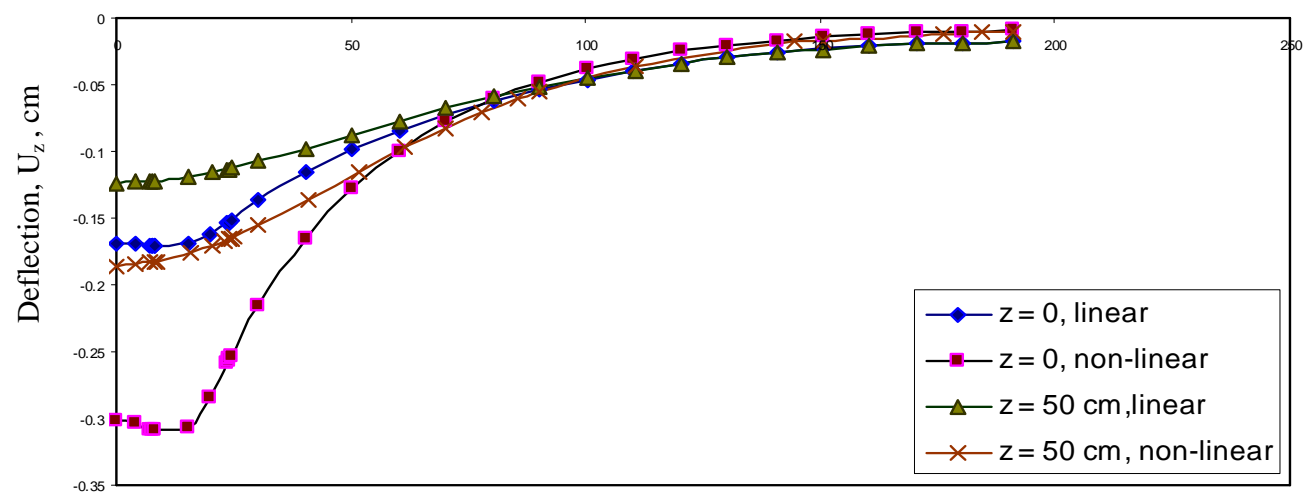

Distance, $\mathrm{cm}$

Figure 14: Comparison of linear and non linear deflections of pavement surface and at depth of $50 \mathrm{~cm}$ through $\mathrm{x}$-axis.

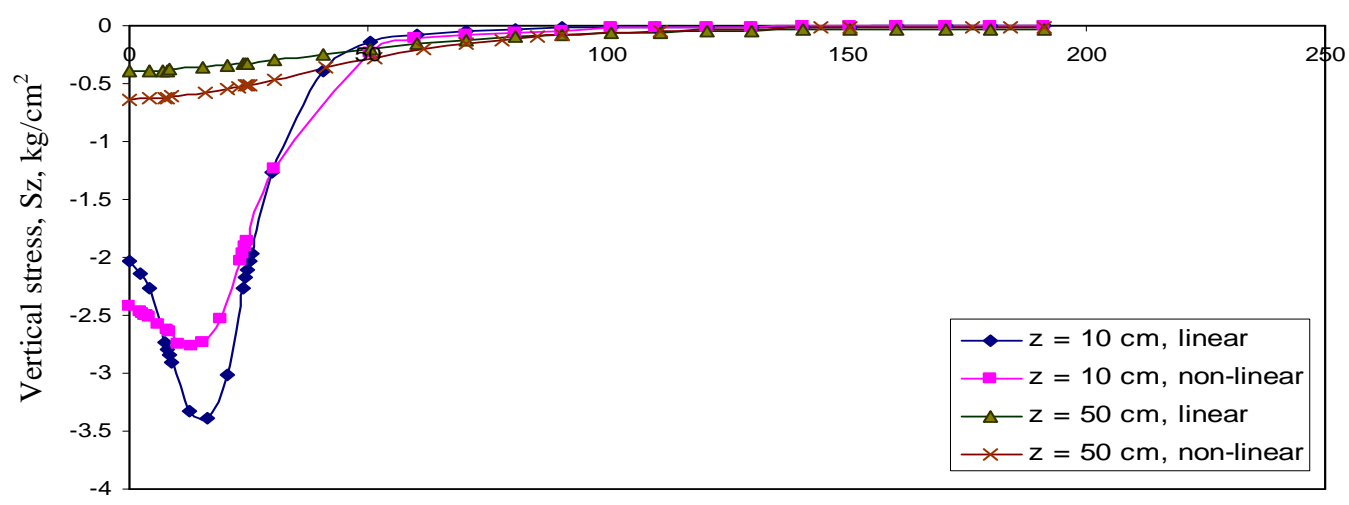

Distance, $\mathrm{cm}$

Figure 15: Comparison of linear and non linear vertical stresses $\left(S_{z}\right)$ at depths of 10 and $50 \mathrm{~cm}$ through $\mathrm{x}$-axis. 


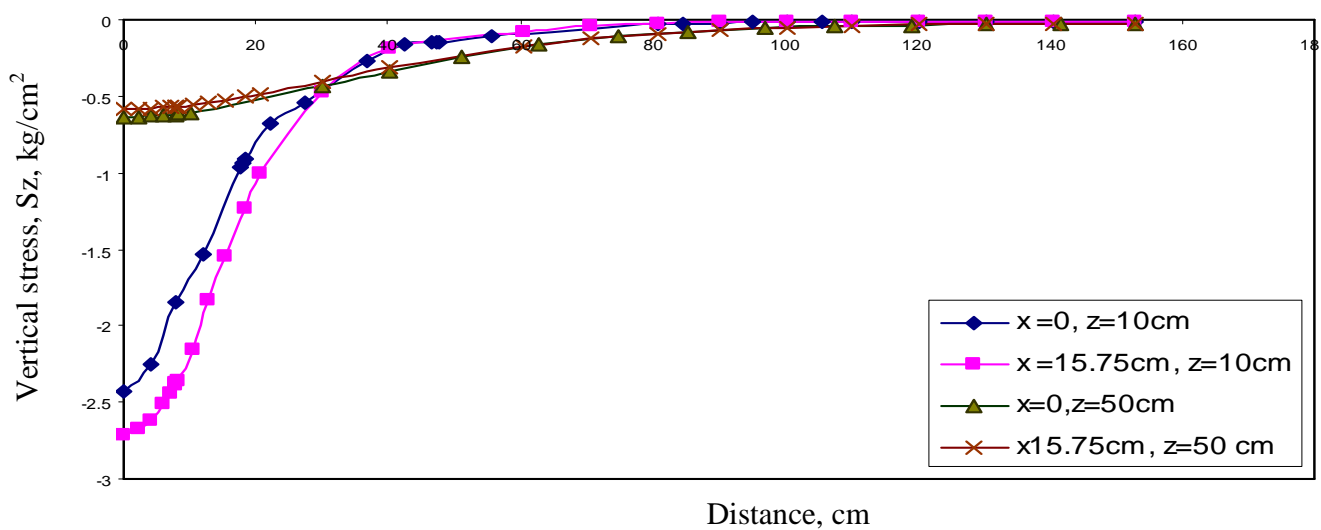

Figure 16: Non linear vertical stresses $\left(S_{z}\right)$ at depths of 10 and $50 \mathrm{~cm}$ through y-axis and C.L. of wheel.

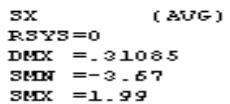

Fia. 17a: (Sx)
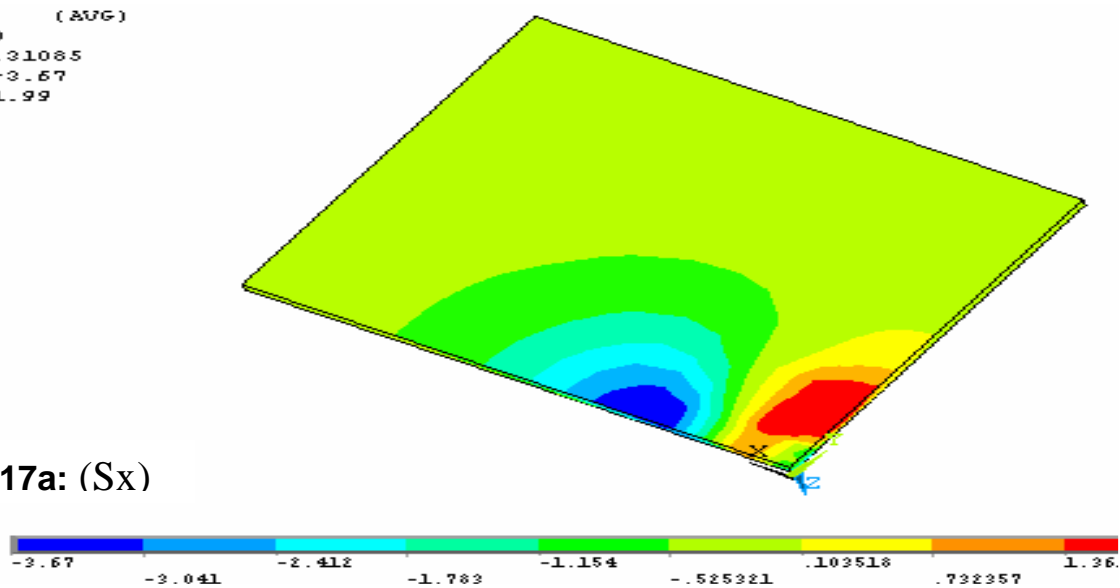

$\operatorname{DMX}=-31085$
$\operatorname{SMn}=-4.262$
$\operatorname{SMX}=2.53$

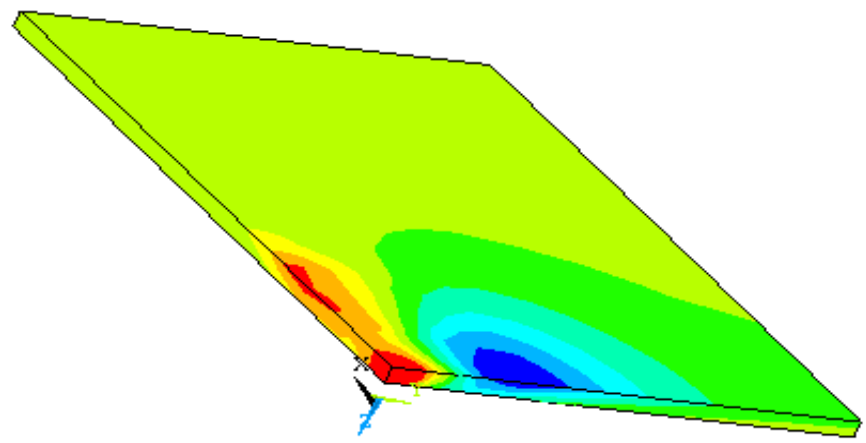

Fig. 17b: (Sy)

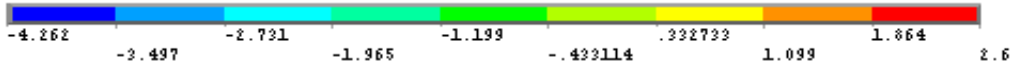


DUX $=.31085$

$\sin \alpha=-3-862$

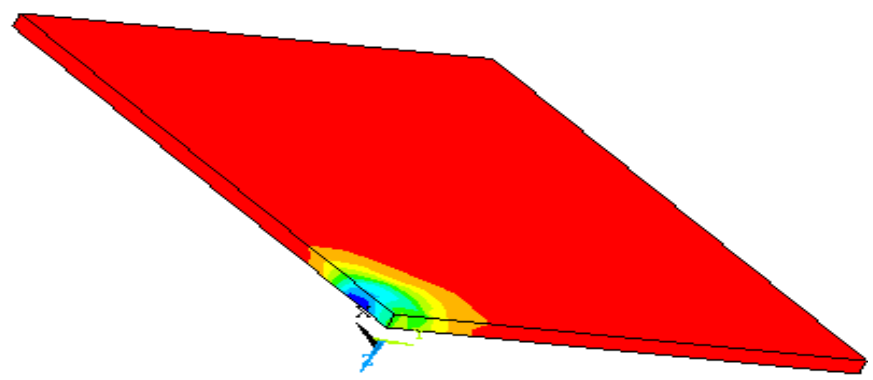

Fig. 17c: $(\mathrm{Sz})$

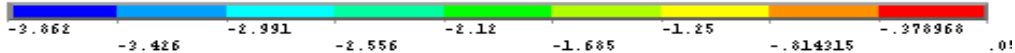

$\operatorname{DEx}=-185447$

$\sin =-55775$

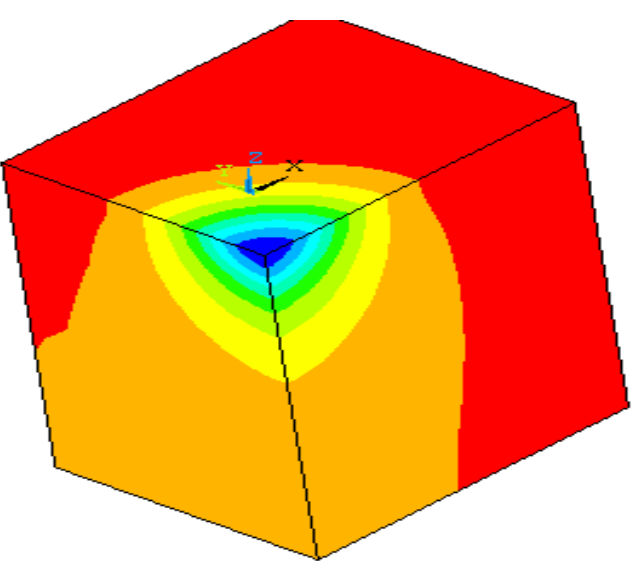

Fia. 17d: $S z$. at $z=50 \mathrm{~cm}$

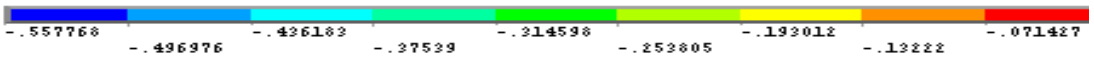

$\mathrm{DMx}=.052424$

$\sin =-1.959$

$\operatorname{sex}=.169$

Fig. 17e: Sz through pavement
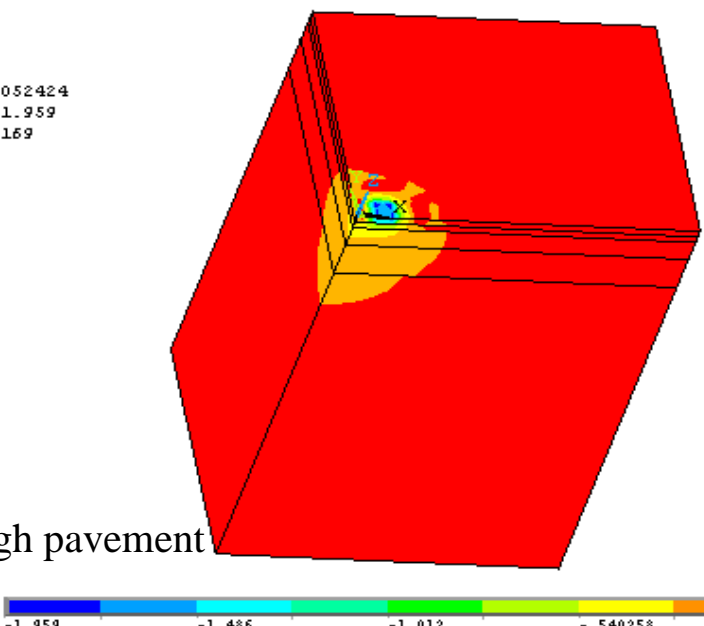

$-1.723$

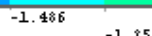

$-1.013$

$-.776811$

$-.303906$

Figure 17: Non linear stresses at bottom of surface layer and different depths of pavement. 
The tire pressure effect on pavement responses considering linear and non linear analysis was performed. The increase of tire pressure from 5.77 to $8.44 \mathrm{~kg} / \mathrm{cm}^{2}$ increases the deflection and stress through pavement for both linear and non linear analysis as shown in Figs. 18-22. The deflection through the C.Ls of wheel and dual wheels assembly are nearly the same. But, the stress at C.L. of dual wheels assembly is slightly larger than that at large depth as presented in Figs.18-20. The pavement surface deflection is affected by wheel position with non-linear analysis as given in Fig. 21.

The effect of wheel magnitude ranging between 8.2 and $9.3 \mathrm{t}$ with the same tire pressure on pavement responses was performed. The deflections especially at surface increase with increasing the magnitude of wheel load in spite of contact pressure equality as shown in Fig. 23-24. Also, the stresses through the pavement were increased owing to increasing wheel load as given in Fig. 25.

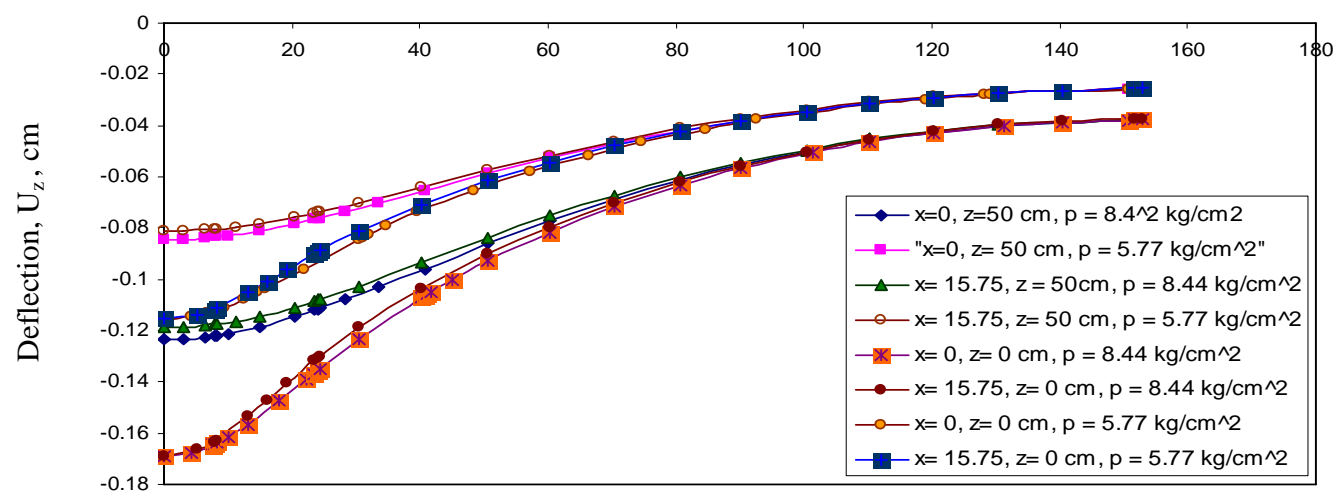

Distance, $\mathrm{cm}$

Figure 18: Comparison of linear deflections of pavement surface and at depth of $50 \mathrm{~cm}$ through y-axis and C.L. of wheel due to different tire pressure intensities.

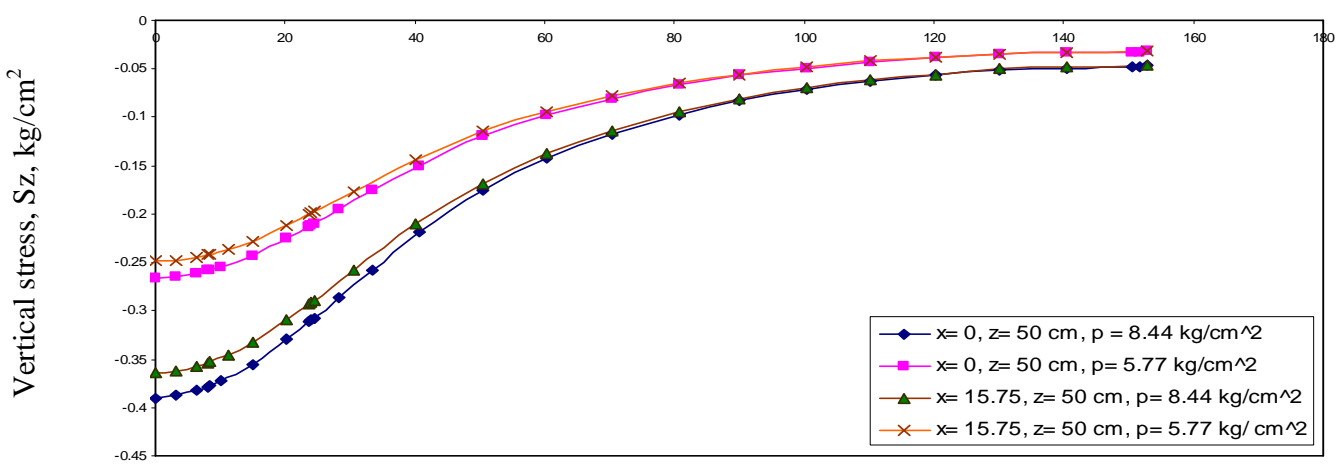

Distance, $\mathrm{cm}$

Figure 19: Comparison of linear vertical stress at depth of $50 \mathrm{~cm}$ through y-axis and C.L. of wheel due to different tire pressure intensities. 


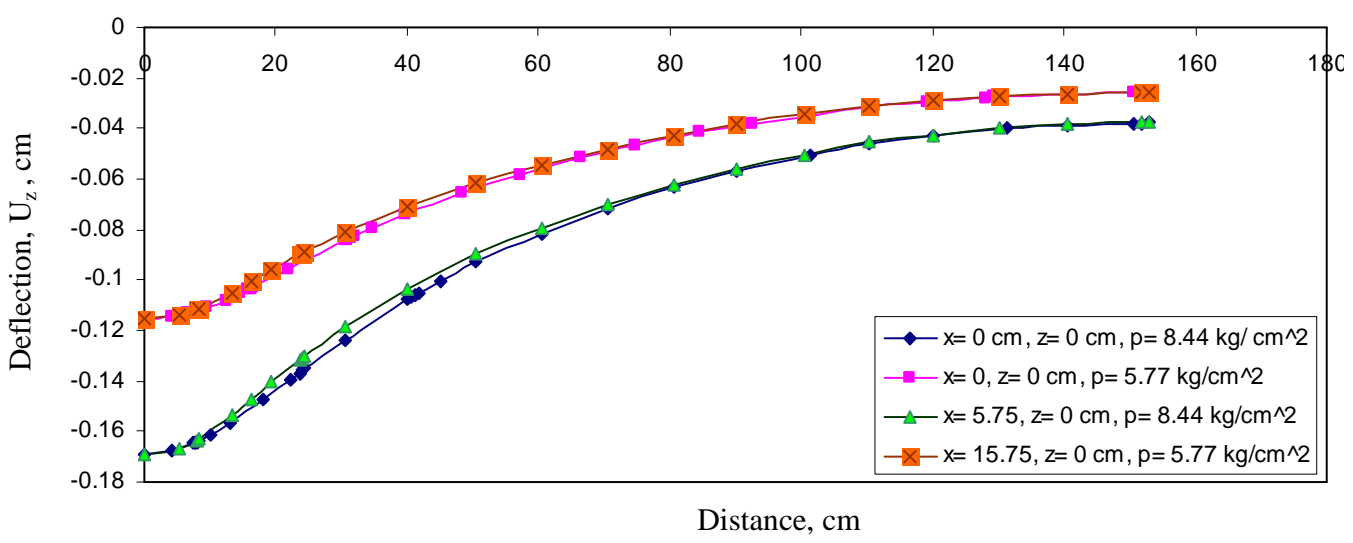

Figure 20: Comparison of non linear deflections of pavement surface through y-axis and C.L. of wheel due to different tire pressure intensities.

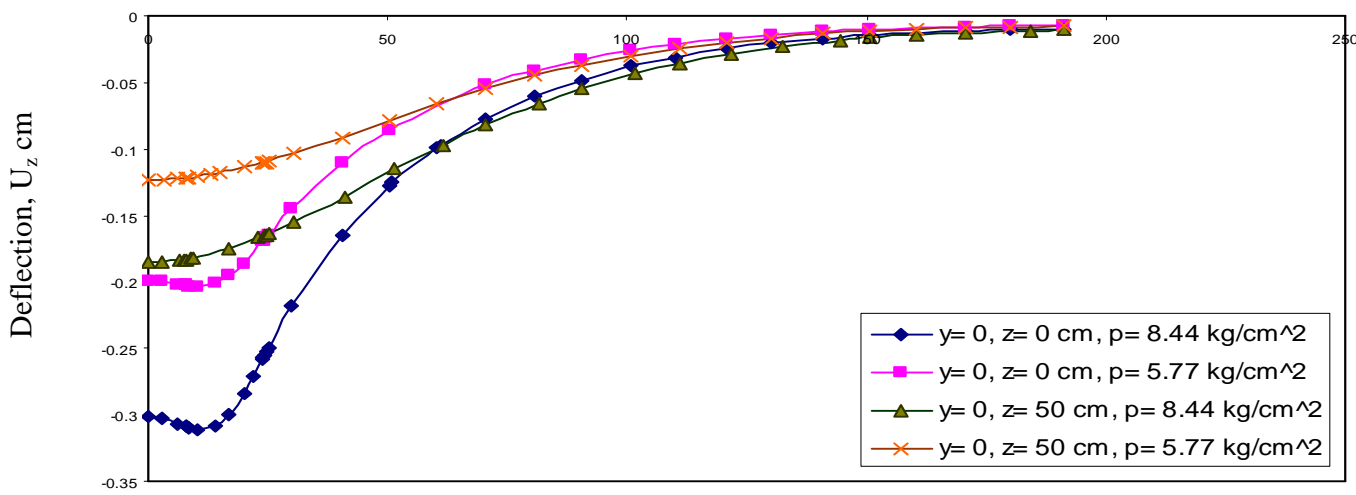

Distance, $\mathrm{cm}$

Figure 21: Comparison of non linear deflections of pavement surface and at depth $50 \mathrm{~cm}$ through $\mathrm{x}$-axis due to different tire pressure intensities.

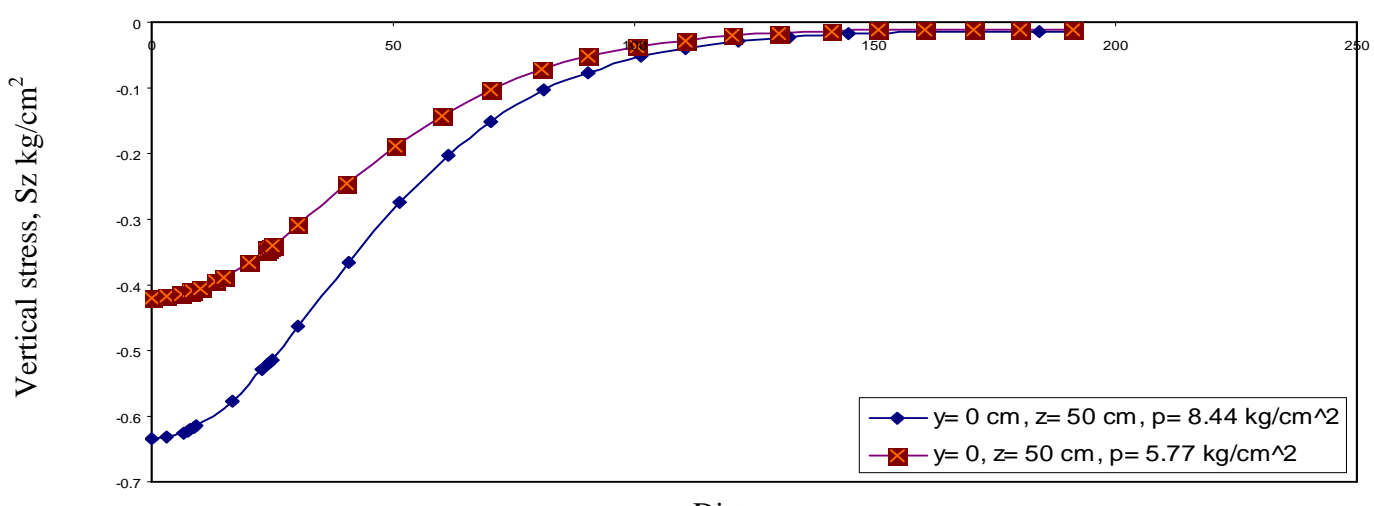

Distance, $\mathrm{cm}$

Figure 22: Comparison of non linear vertical stress at depth of $50 \mathrm{~cm}$ through $\mathrm{x}$-axis due to different tire pressure intensities. 


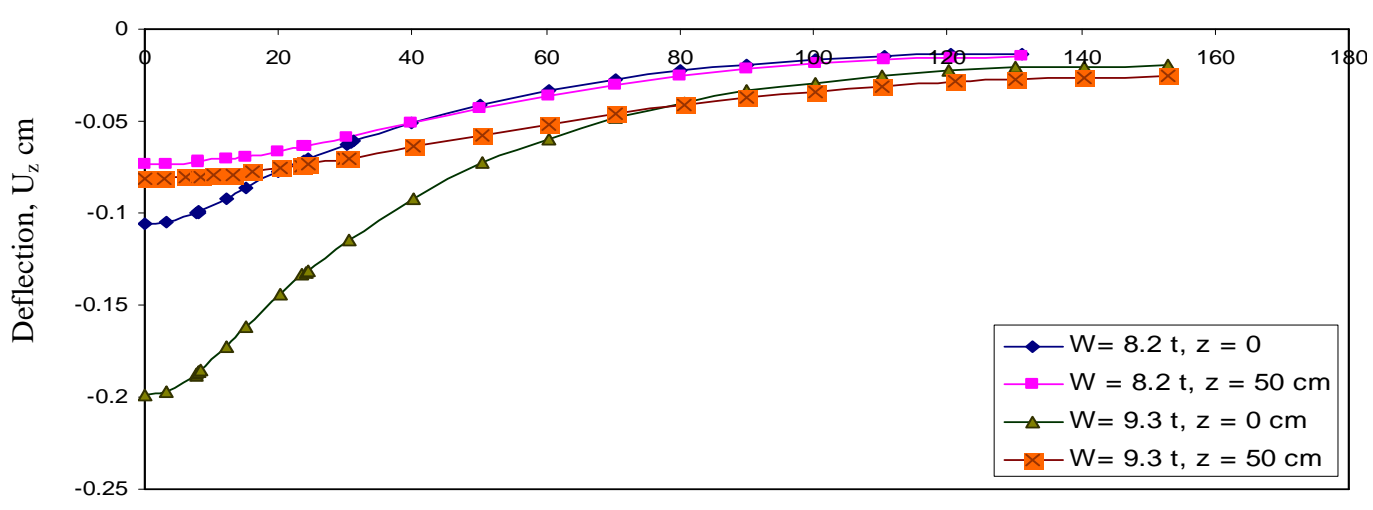

Distance, $\mathrm{cm}$

Figure 23: Comparison of non linear deflections of pavement surface and at depth of $50 \mathrm{~cm}$ through C.L. of wheel due to different wheel loading.

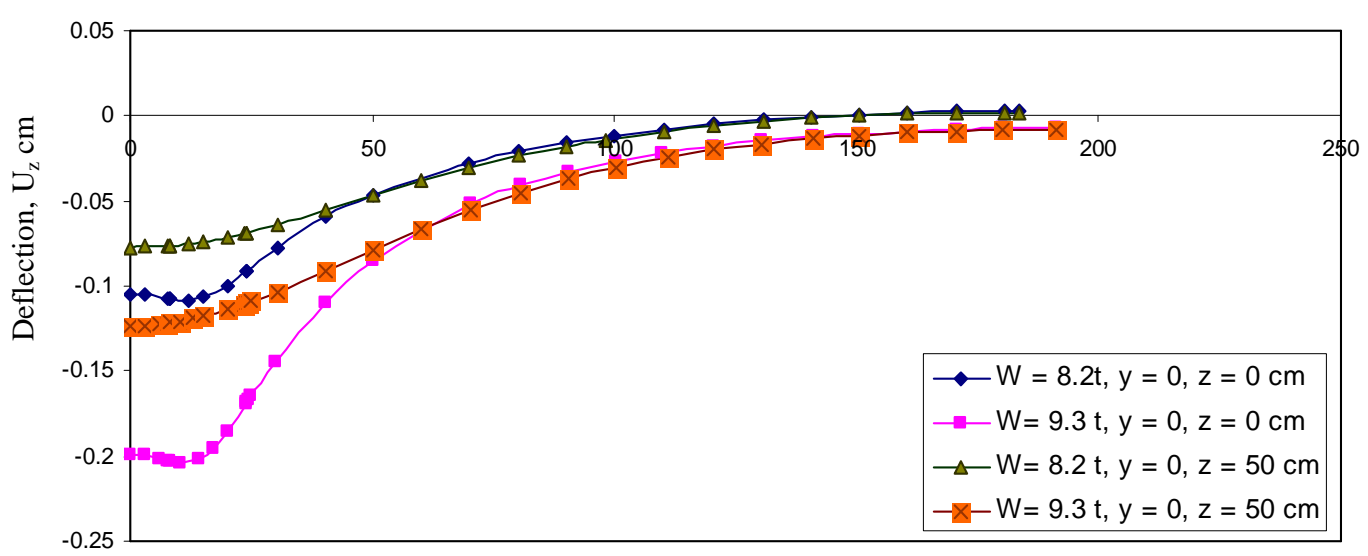

Distance, $\mathrm{cm}$

Figure 24: Comparison of non linear deflections of pavement surface and at depth of $50 \mathrm{~cm}$ through $\mathrm{x}$-axis due to different wheel loading.

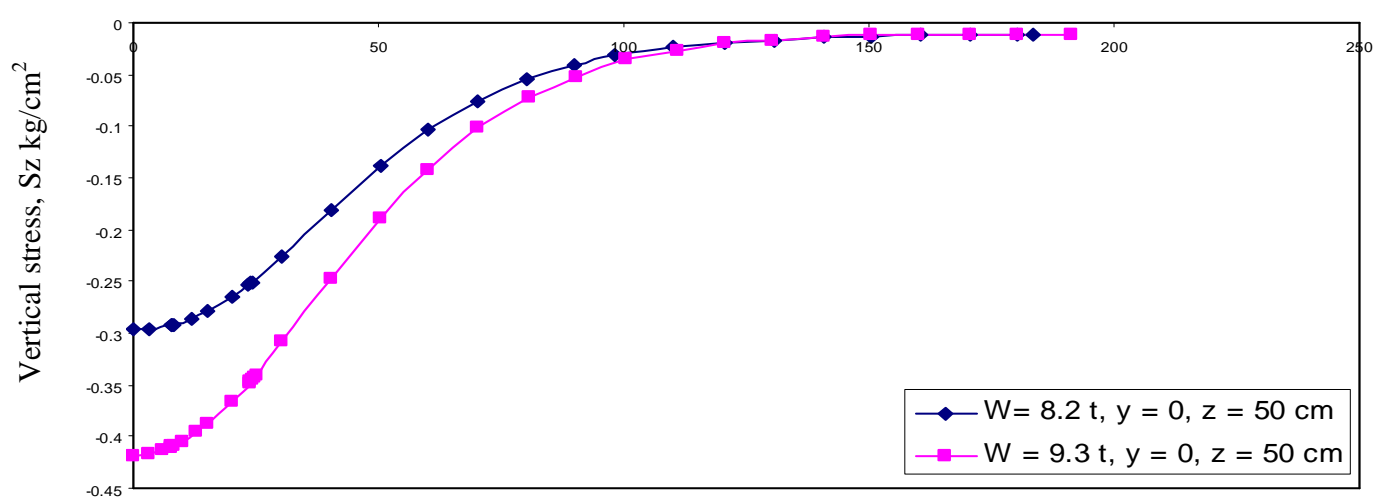

Distance, $\mathrm{cm}$

Figure 25: Comparison of non linear vertical stress pavement depth of $50 \mathrm{~cm}$ through $x$-axis due to different wheel loading. 
The surface layer rigidity effect on pavement responses due to tire pressure equal to $5.77 \mathrm{~kg} / \mathrm{cm}^{2}$ was conducted considering linear and non linear analysis. The increase of surface layer rigidity $\left(\mathrm{s}_{1}=\mathrm{s}_{1} \mathrm{n}\left(\mathrm{E}_{1}=30000 \mathrm{~kg} / \mathrm{cm}^{2}, \mathrm{E}_{2}=15000 \mathrm{~kg} / \mathrm{cm}^{2}, \mathrm{~s}_{2}=\mathrm{s}_{2} \mathrm{n}\left(\mathrm{E}_{1}=\right.\right.\right.$ $\left.\left.20000 \mathrm{~kg} / \mathrm{cm}^{2}, \mathrm{E}_{2}=10000 \mathrm{~kg} / \mathrm{cm}^{2}\right), \mathrm{s}_{4}=\mathrm{s}_{4} \mathrm{n}\left(\mathrm{E}_{1}=10000 \mathrm{~kg} / \mathrm{cm}^{2}, \mathrm{E}_{2}=5000 \mathrm{~kg} / \mathrm{cm}^{2}\right)\right)$; decreases the resulting deflection through pavement depending on pavement depth as shown in Figs 26-30. The deflection through $\mathrm{x}$-axis reflects the resulting equivalent wheel load through pavement as given in Figs. 28-30.

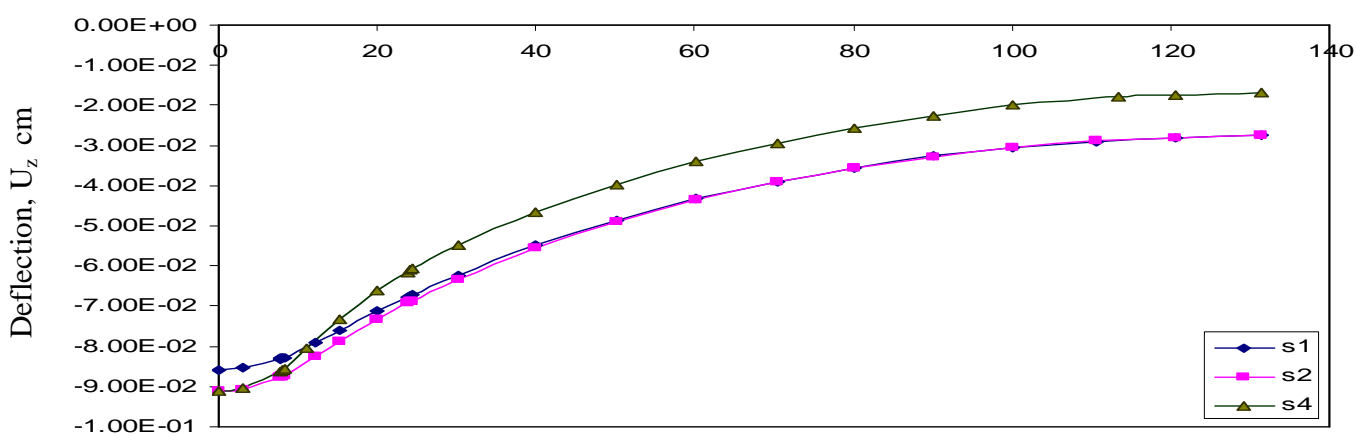

Distance, $\mathrm{cm}$

Figure 26: Comparison of linear deflections of pavement surface through C.L. of wheel for different surface layer rigidities.

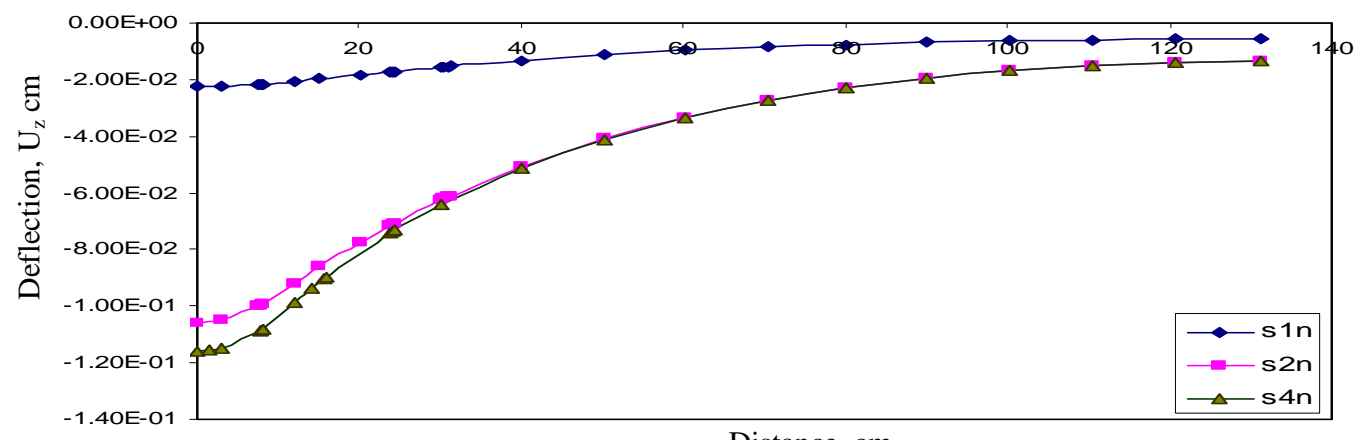

Distance, $\mathrm{cm}$

Figure 27: Comparison of non linear deflection of pavement surface through C.L. of wheel for different surface layer rigidities.

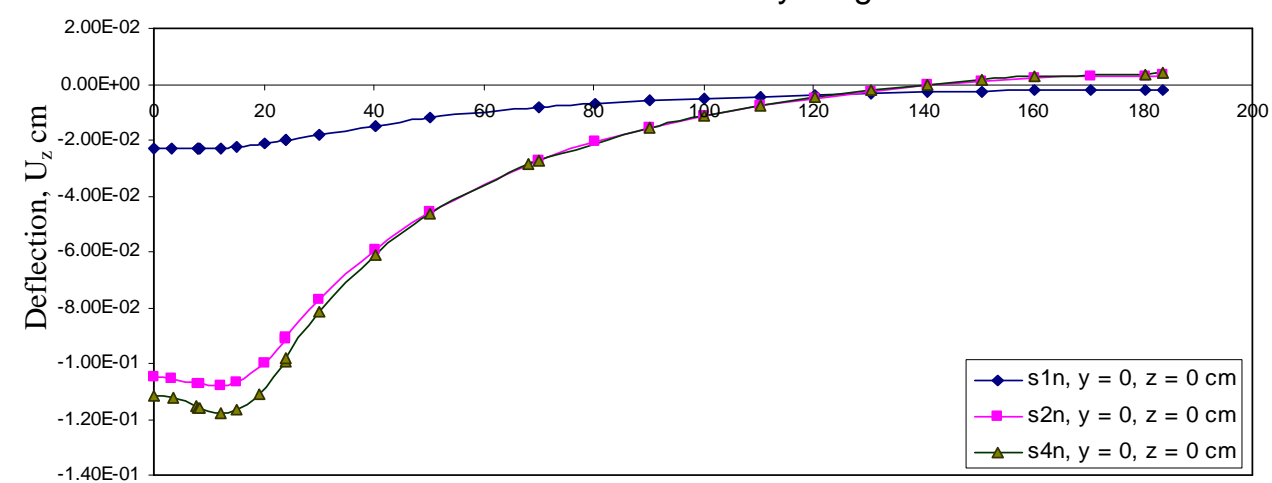

Distance, $\mathrm{cm}$

Figure 28: Comparison of non linear deflection of pavement surface through $\mathrm{x}$-axis for different surface layer rigidities. 


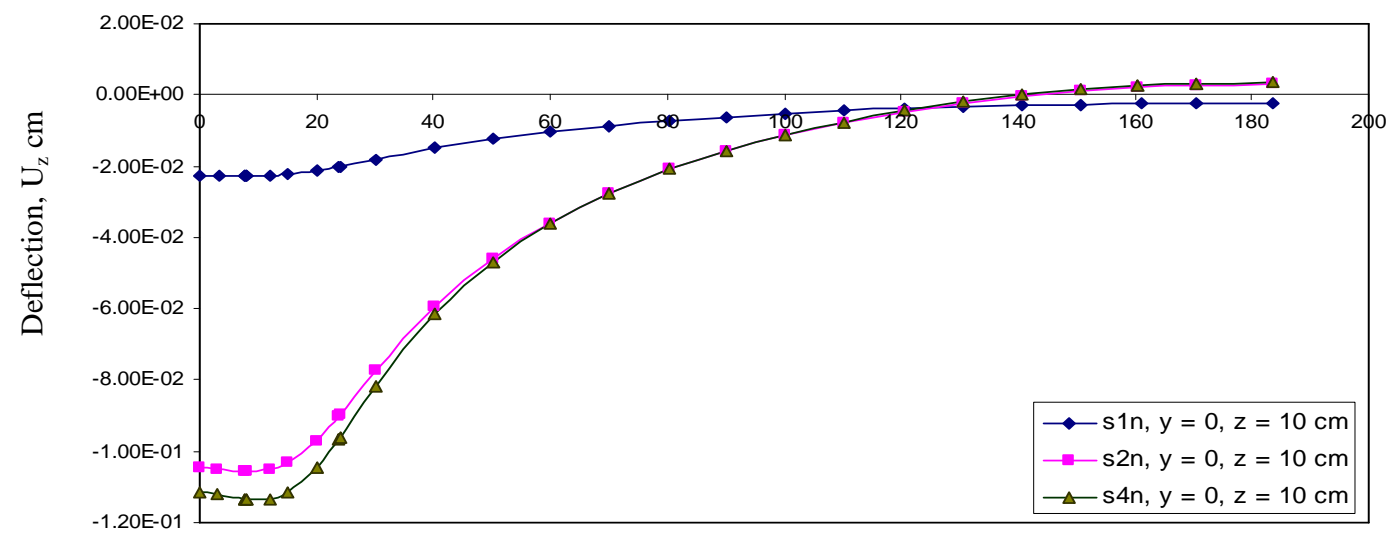

Distance, $\mathrm{cm}$

Figure 29: Comparison of non linear deflection at pavement depth of $10 \mathrm{~cm}$ through $\mathrm{x}$-axis for different surface layer rigidities.

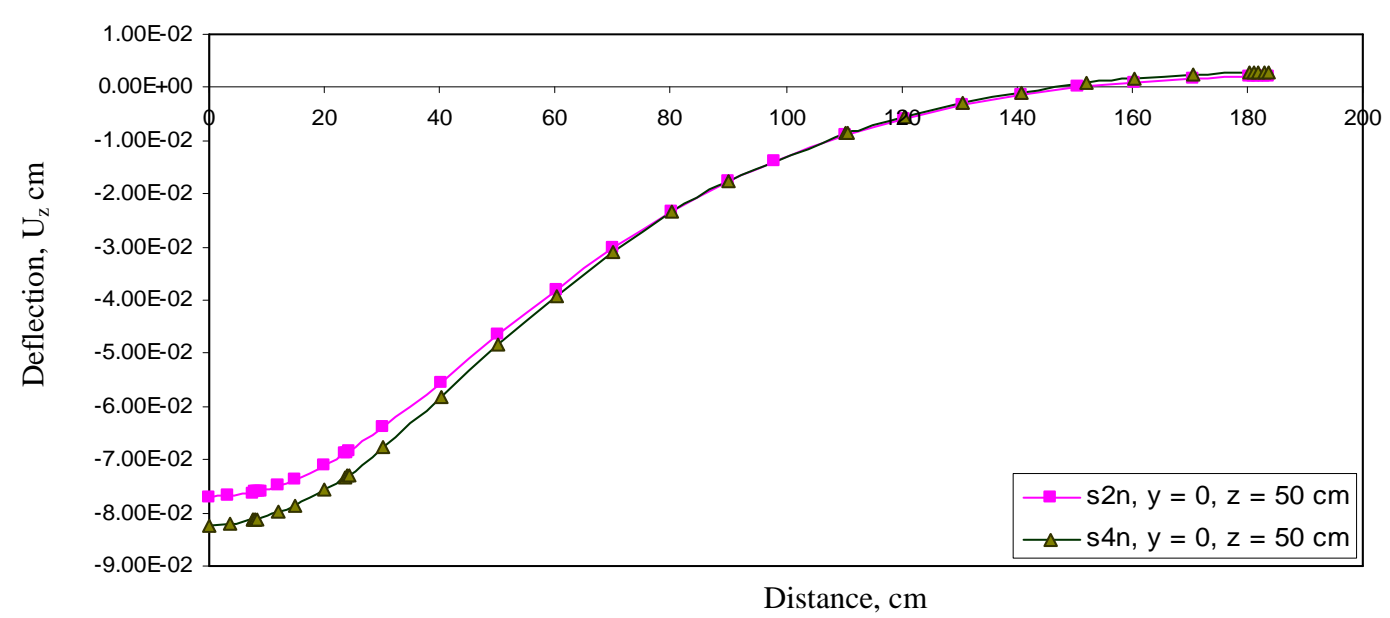

Figure 30: Comparison of non linear deflection at pavement depth of $50 \mathrm{~cm}$ through $x$-axis for different surface layer rigidities.

For linear and non-linear analysis, the vertical stress at depths 10 and $50 \mathrm{~cm}$ through symmetry axis through both C.L. of wheel and $\mathrm{x}$-axis is larger in case of lower surface layer rigidity especially through small depths as shown in Figs. 31-38. On the other hand the tensile stress (tangential stress) is large through the load acting zone with high surface layer rigidity as given in Figs. $\mathbf{3 4}$ and 37. It may be owing to layer stiffness increasing and its proportioning with lower layer. The resulting deflections are similar as those of Boussinesq's results. 


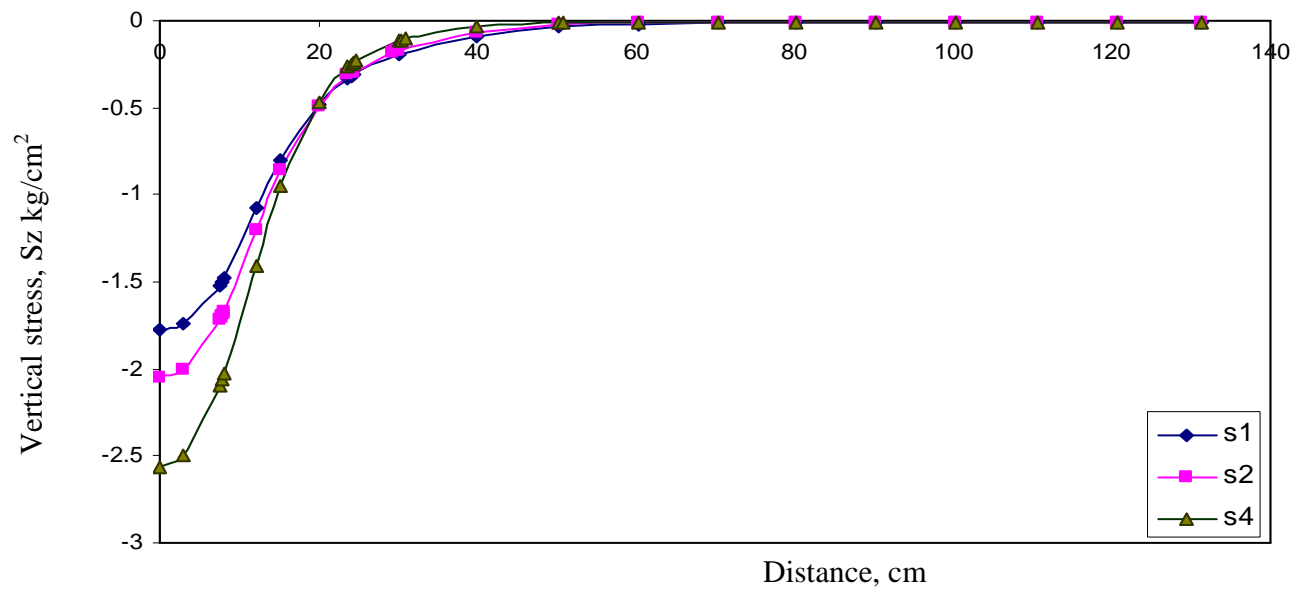

Figure 31: Comparison of linear vertical stress at pavement depth of $10 \mathrm{~cm}$ through C.L. of wheel for different surface layer rigidities.

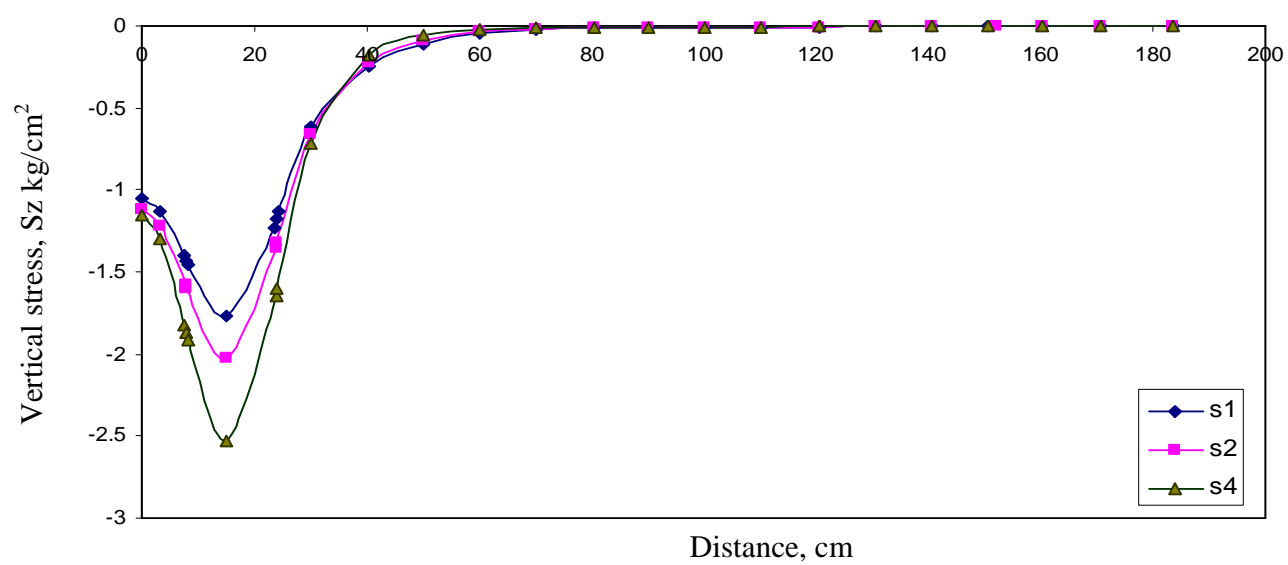

Figure 32: Comparison of linear vertical stress at pavement depth of $10 \mathrm{~cm}$ through $\mathrm{x}$ axis for different surface layer rigidities.

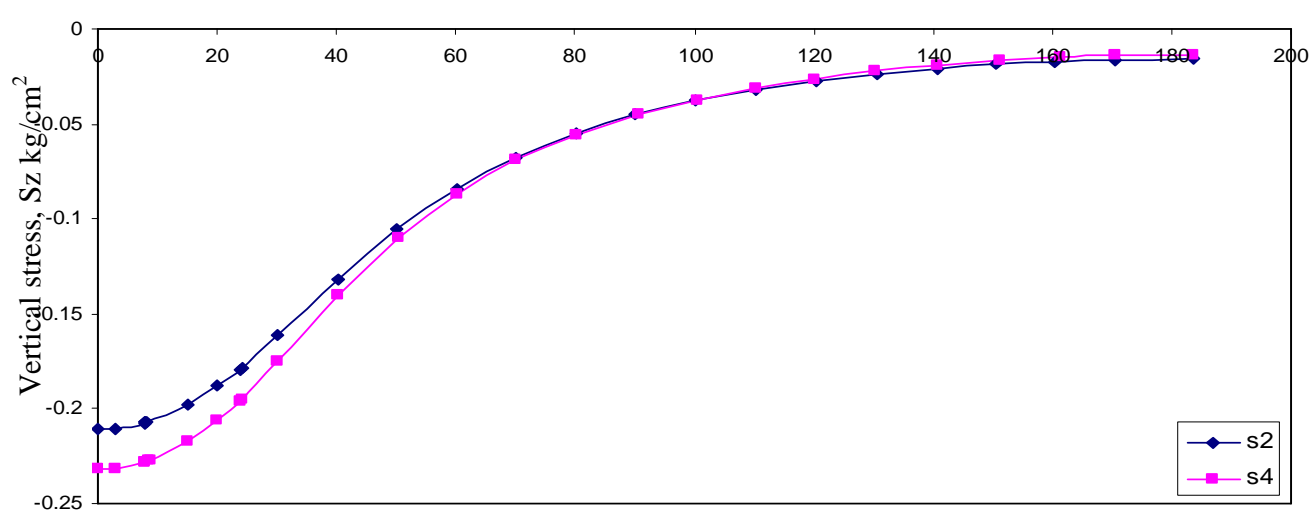

Distance, $\mathrm{cm}$

Figure 33: Comparison of non linear vertical stress at pavement depth of $50 \mathrm{~cm}$ through $\mathrm{x}$-axis for different surface layer rigidities. 


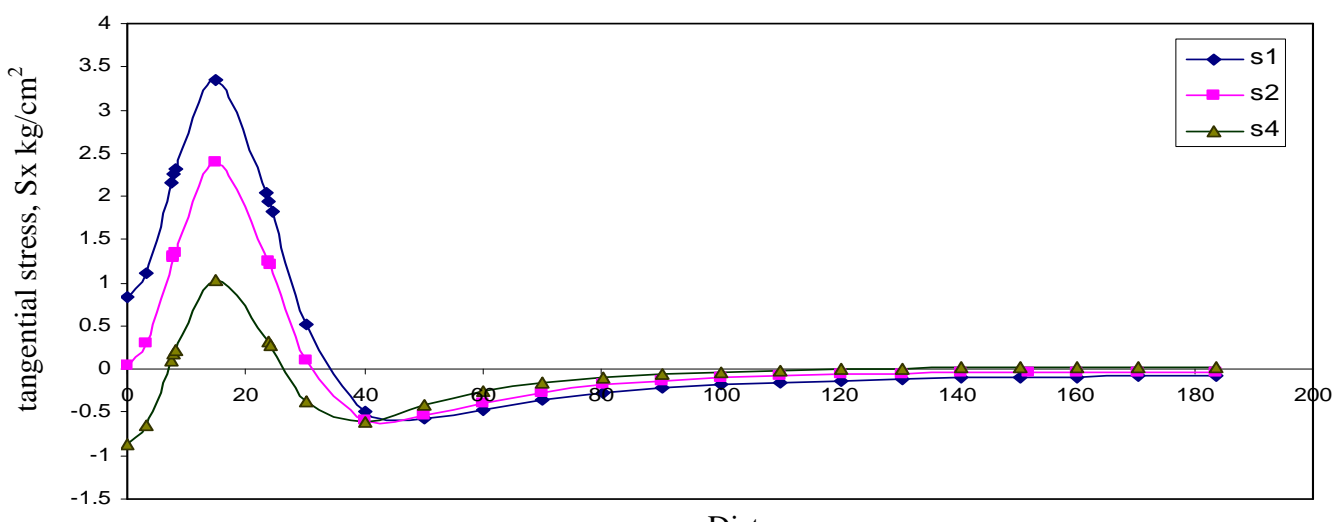

Distance, $\mathrm{cm}$

Figure 34: Comparison of linear shear stress $\left(S_{x}\right)$ at pavement depth of $10 \mathrm{~cm}$ through $\mathrm{x}$-axis for different surface layer rigidities.

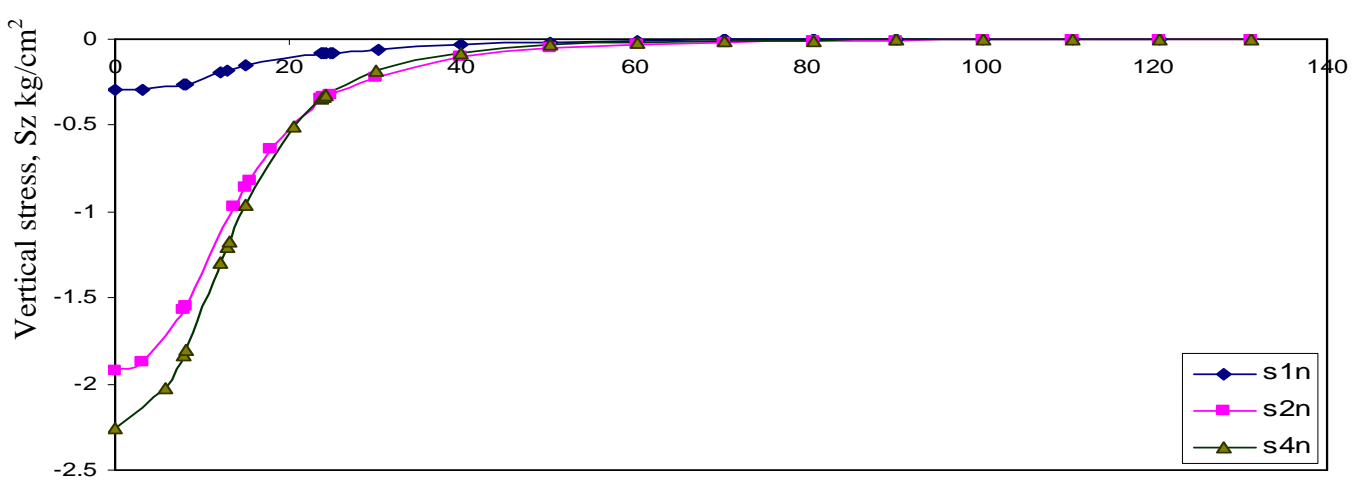

Distance, $\mathrm{cm}$

Figure 35: Comparison of non linear vertical stress at pavement depth of $10 \mathrm{~cm}$ through C.L. of wheel for different surface layer rigidities.

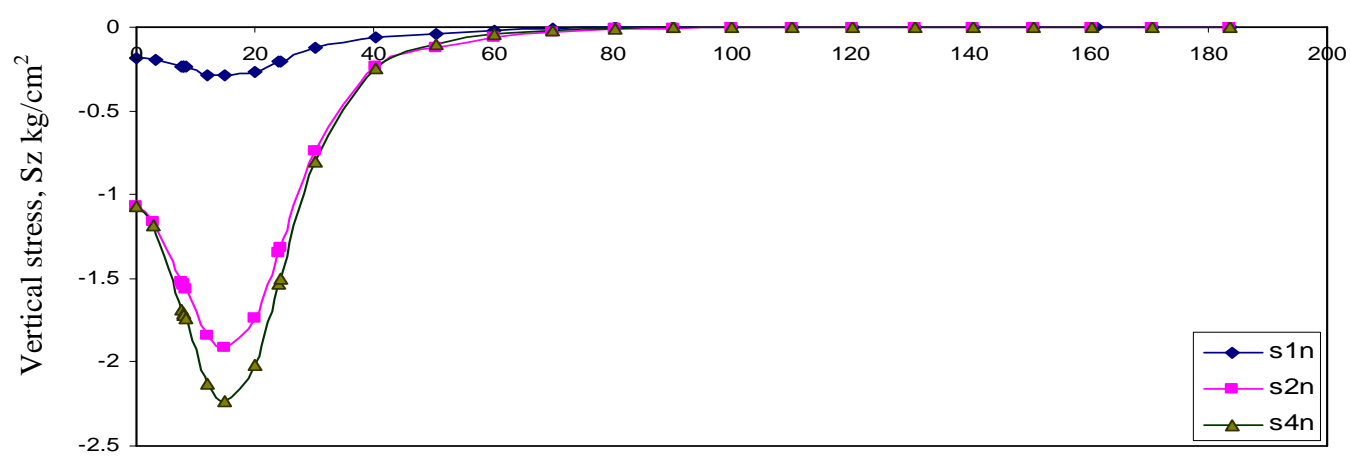

Distance, $\mathrm{cm}$

Figure 36: Comparison of non linear vertical stress at pavement depth of $10 \mathrm{~cm}$ through $\mathrm{x}$-axis for different surface layer rigidities. 


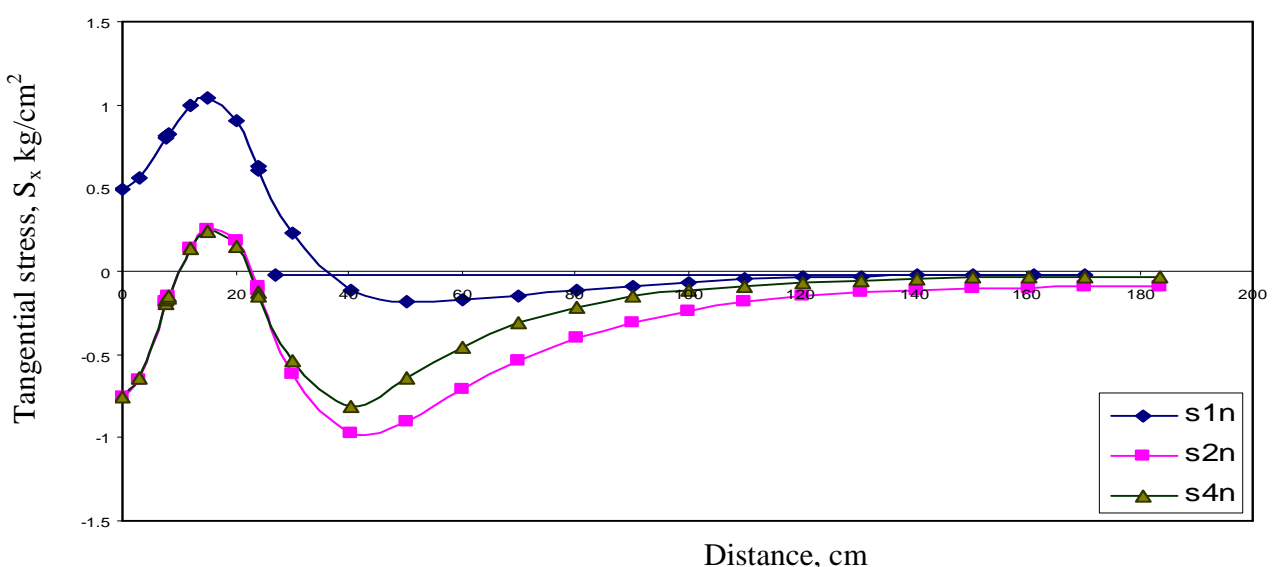

Figure 37: Comparison of non linear shear stress $S_{x}$ at pavement depth of $10 \mathrm{~cm}$ through $\mathrm{x}$-axis for different surface layer rigidities.

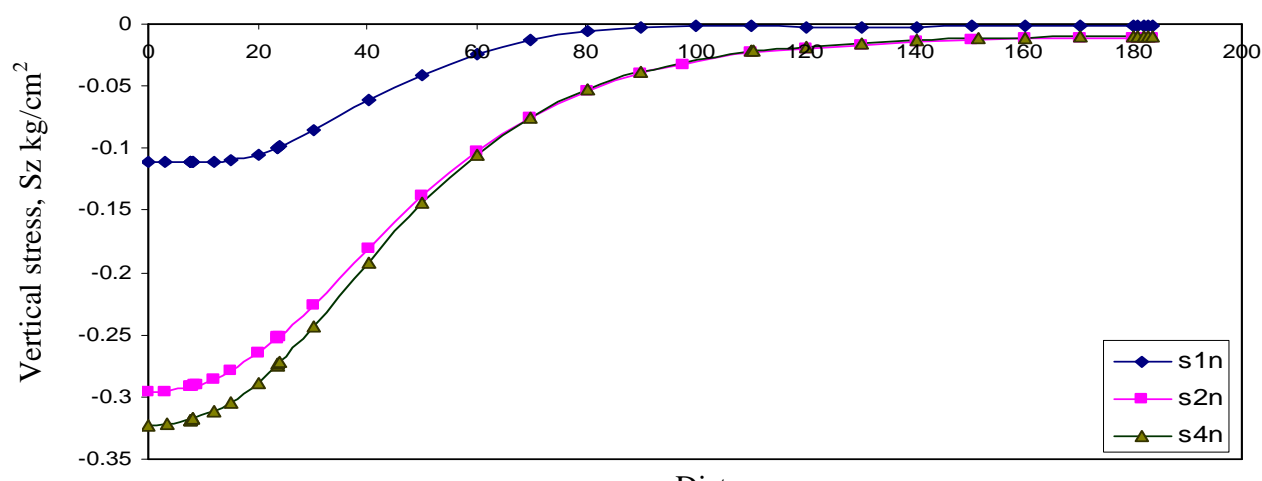

Distance, $\mathrm{cm}$

Figure 38: Comparison of non linear vertical stress at pavement depth of $50 \mathrm{~cm}$ through $\mathrm{x}$-axis for different surface layer rigidities.

\section{CONCLUSIONS}

1. The surface deflection and stress at shallow depths through C.L. of wheel are slightly greater than those at C.L. of wheel assembly configuration, but the difference is negligible at large depths.

2 For linear and non linear analyses, the deflection and the stress through pavement due to tire pressure decrease as the depth from the surface increases.

3. The deflection curves through pavement depth reflect the concept of the resulting equivalent wheel load, which the assembled dual wheels may act.

4. For linear analysis, the maximum vertical stress according to the present analysis is equal to $130 \%$ of that obtained according to the modified Boussinesq's formula or by the 2-D analysis, while surface deflection is less by $10 \%$ than that obtained from the 2$\mathrm{D}$ analysis. 
5. The values of deflection and stress considering non linearity are greater than those obtained from the linear analysis.

6. The pavement responses almost happen within deficient conical zone and sharply decrease beneath surface layer and extend to 2-3 times of wheel breadth roundly.

7. For both linear and non linear analyses, the increase of tire pressure increases the deflection and stress through pavement depending on pavement depth especially under the load acting zone. Those responses increase with increasing the magnitude of wheel load in spite of contact pressure equality. On the other hand, the increase of surface layer rigidity decreases the resulting deflection and stress through pavement.

8. It is desirable to select surface layer of high quality and with enough thickness to resist tensile stresses exposed to the bottom surface of lower asphalt layer.

\section{REFERENCES}

[1] Yoder E.J., and Witczak M.W., "Principles of Pavement Design", A WileyInterscience Publication, John Wiley \& Sons, Inc., New York, 1975.

[2] Roberts, F.L., Tielking, J.T., Middleton, D., Lytton, R.L., and Tseng, K. "Effect of Tire Pressure on Flexible Pavements." Report No.372-IF, Texas Transp. Inst., College Station, Texas 1986.

[3] Bonaquist, R., Churilla, C. and Freund, D., "Effect of Load, Tire Pressure, and Tire Type on Flexible Pavement Response." Transp. Res. Record, (1227), 1989, PP.97-106

[4] Kim O., and Bell C.A., "Effect of Increased Truck Tire Pressure on ASPHALT concrete Pavement" Jour. Transp. Eng., Vol. 115, No. 4, PP. 329-352, 1989.

[5] Sebaaly P.E., Tabatabae, N., "Effect of Tire Parameters on Pavement Damage and Load-Equivalency Factors" Jour. Transp. Eng., Vol. 118, No. 6, PP. 805819, 1992

[6] Kim D., Salgado R. and Altschaeffi A. G., "Effects of Super-single Tire Loadings on Pavements" J. Transp. Engrg., Vol.131, Issue 10, pp.732-743, 2005.

[7] Brown S.F., "Achievements and Challenges in Asphalt Pavement Engineering" ISAP-8 ${ }^{\text {th }}$ International Conference on Asphalt Pavements - Seattle, 1997.

[8] Freeman R.B. and Harr M.E., "Stress Prediction for Flexible Pavement Systems" J. Transp. Engrg., Vol.130, Issue 7, pp.495-502, 2004.

[9] Hadi M.N.S., "Non-linear Finite Element Analysis of Flexible Pavements", Advance Engineering Software, 34, 2003, PP. 657-662.

[10] Moriyoshi A., Partl M. N., Denpouya H. and Takano S., "Damage Analysis for Flexible Pavement at High Temperatures Using Visco-elastic Hybrid FEM", Master Science paper, faculty of Eng., Hokkaido University, Japan, 2002.

[11] Park, S-W; Lytton, RL, "Effect of Stress-Dependent Modulus and Poisson's Ratio on Structural Responses in Thin Asphalt Pavements" Journal of Transportation Engineering, Volume: 130 Issue: 3, 2004, PP 387-394, Reston, USA

[12] Abd Alla E.M., "Simplified Method for Flexible Pavement Design Using Finite Element Method (FEM)", Bulletin of the Faculty of Eng., Assiut University, Vol. 25, No. 2, July 1997. 
[13] Per Ulidtz, "Pavement Analysis" Textest Book, Elsevier Science Publ. B.V., 1987.

[14] ANSYS Program, Vergion-8, SAS IP, Inc1 Second Edition, 1996

[15] Peatie k. R., "Flexible Pavement Design Procedure in Europe", Transportation Eng. Jour., Jan. 1977.

[16] Abou-Ahmed K.A., "Design of Flexible Pavements as a Function of Subgrade Bearing Capacity", $1^{\text {st }}$ Alexandria Conference on Structural and Geotechnical Engineering, 1-3 December 1990.

[17] Abd Alla E.M., "Flexible Pavement Design Using Deflection Criterion", Bulletin of the Faculty of Eng., Assiut University, Vol. 26, No. 1, January 1998.

[18] Enieb M.O., "Elasto-Plastic Critical State Model with Strain Localization in soil Structures", Ph.D. dissertation, University of Innsbruck, Austria, 2004.

[19] Mamlouk M.S. and Davies T.G., "Elasto-Dynamic Analysis of Pavement Deflections" Jour. of Transp. Eng., Vol. 110, No. 6, Nov. 1984.

\section{التحليل ثلاثي الإبعاد للرصف المرن المعرض لأحمال مرورية باستخدام العناصر المحددة المرة المعرد}

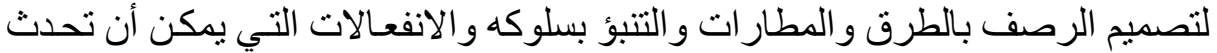

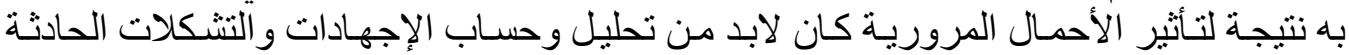

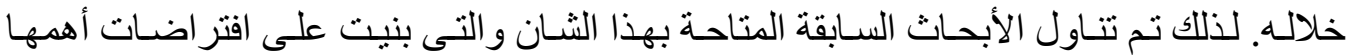

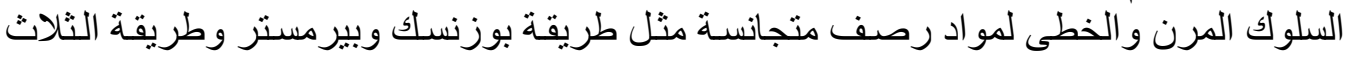

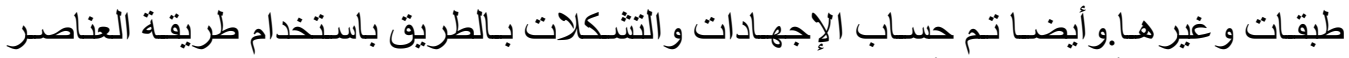

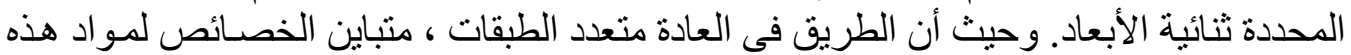

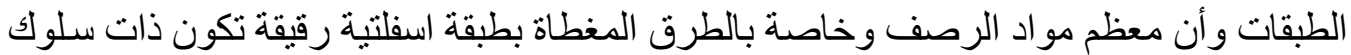

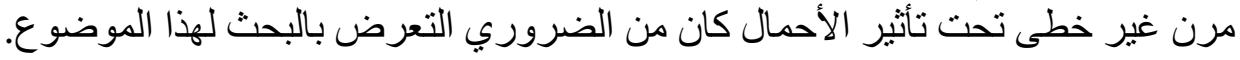

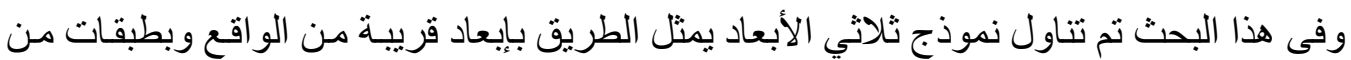

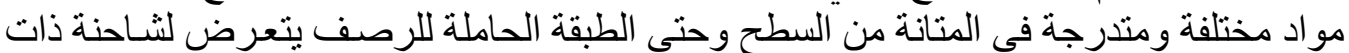

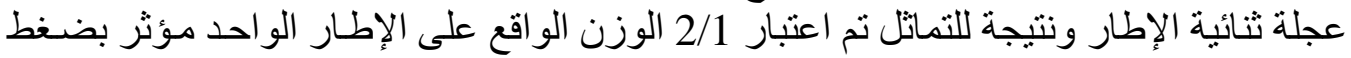

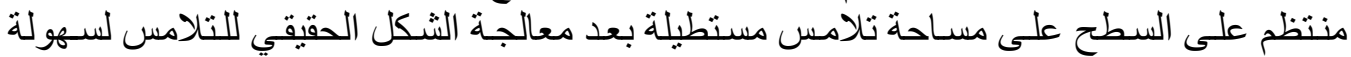
التناول و التحليل وذلك باستخدام برنـامج الحاسـ الآلي ANSYS إصدار 8 وبطريقة العناصر

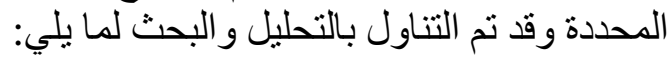

1- الإجهادات و التشكلات بطبقات الرصف باعتبار سلوكها مرن وخطيا. 2- الإجهادات و التشكلات بطبقات الرصف باعتبار سلوكها مرن و غير خطيا.

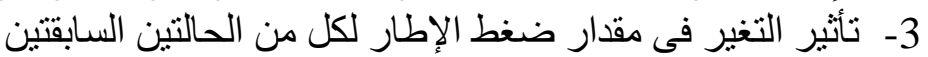
4- تأثير التغير فى مقدار وزن المحور عند تسـاوى ضـغط الإطـار لكل مـن السـلوك المـرن الخطى و الغير خطى.

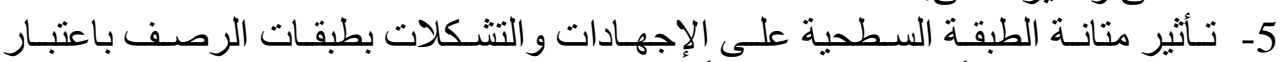
سلوكها مرن خطياً و مرن غير خطئاً. 
وقد تم استخلاص عدة نتائج من البحث أهمها:

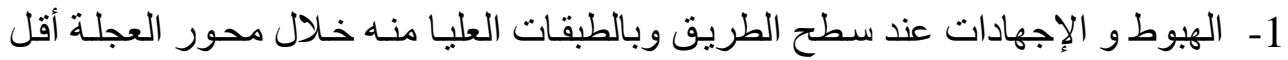
بدرجة ما عنه خلال محور الإطار الواحد ويتلاشى هذا الفرق كلما زاد البعد عن سطح

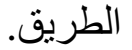
2- الهبوطو و الإجهادات خلال الطريق تتنـاقص مع تناقص كل من الضغط داخل الإطـار وزيادة البعد عن سطح الطريق.

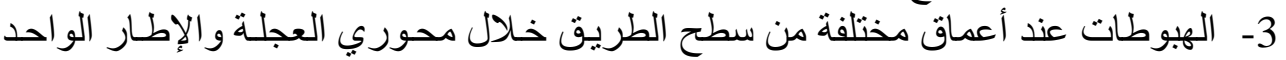

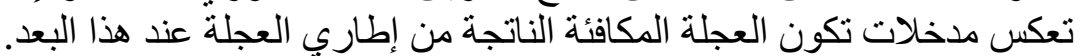

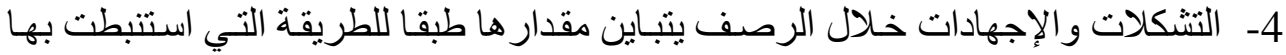

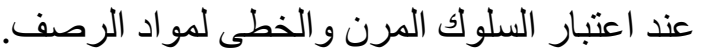

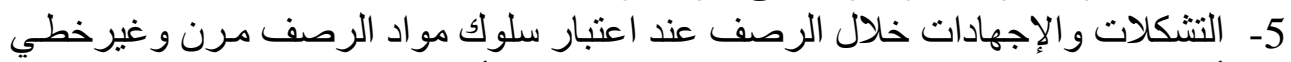

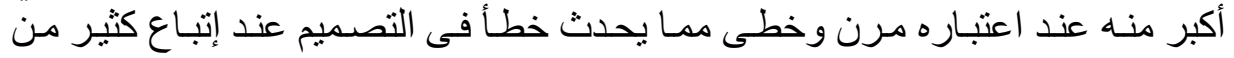

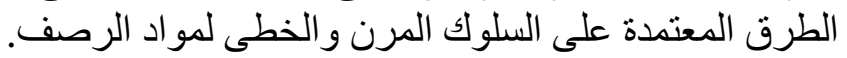

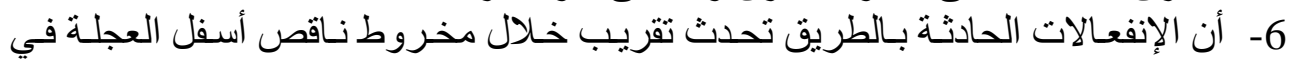
مساحة تمتد 2-3 عرض العجلة المؤثرة وان القيمة القئنة القصوى تكون خلال محور العجلة بالطبقات السفلي من الرصف.

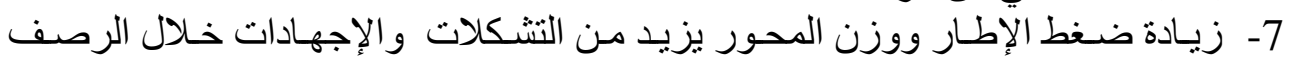

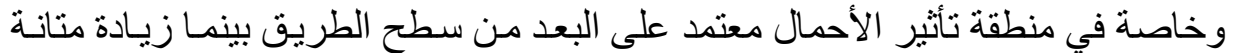
الطبقة السطحية يقلل من هذه الانفعالات الاتحال

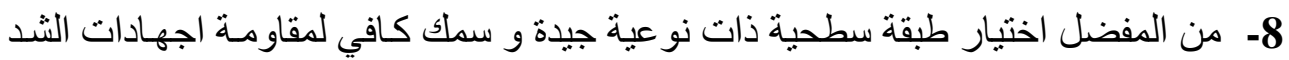
المحتمل تعرض سطحها أو سطح الطبقة الر ابطة السفلي لهار الهاء 